\title{
Öğretmen Kariyer Basamaklarının Oluşturulmasına İlişkin Görüşlerin İncelenmesi: Karma Yöntem Araş̧ırmas1 ${ }^{1}$
}

İzzet KAPLAN

Milli Eğitim Bakanlığ1

gizzetkaplan@gmail.com

Murat Gürkan GÜLCAN

Gazi Üniversitesi

mgulcan@gazi.edu.tr

Gönderilme Tarihi: 15/04/2020

Kabul Tarihi: $29 / 11 / 2020$

Yayınlanma Tarihi: 30/11/2020

DOI: $\underline{10.30855 / \text { gjes.2020.06.03.007 }}$

\begin{tabular}{|c|c|}
\hline Makale Bilgileri & ÖZET \\
\hline $\begin{array}{l}\text { Anahtar Kelimeler: } \\
\text { Kariyer } \\
\text { basamakları, } \\
\text { Maarif müfettişi, } \\
\text { Okul müdürü, } \\
\text { Öğretmenin } \\
\text { mesleki gelişimi, } \\
\text { Öğrenci başarısı }\end{array}$ & $\begin{array}{l}\text { Bu çalışmanın amacı, Türkiye'de öğretmen kariyer basamaklarının } \\
\text { oluşturulmasına ilişkin maarif müfettişleri, okul müdürleri ve öğretmenlerin } \\
\text { görüşlerini belirlemektir. Kariyer basamaklarının oluşturulması, öğretmenin } \\
\text { mesleki gelişiminde önemli gelişmeler sağlayabilecek bir katalizör olup } \\
\text { olamayacağı bu araştırmada ortaya konulmaya çalışılmıştır. Öğretmen, okul } \\
\text { yöneticileri ve maarif müfettişlerinin görüşlerine göre; "Kariyer basamaklarının } \\
\text { oluşturulmasının öğretmenin mesleki gelişimine etkisi, kariyer basamaklarının } \\
\text { ne şekilde oluşturulacağı, öğretmen kariyer basamaklarında yükselmede hangi } \\
\text { kriterlerin kullanılması gerektiği, üst kariyer basamağındaki öğretmenden nasıl } \\
\text { yararlanılabileceği” sorularına cevaplar aranmıştır. Araştırmada karma } \\
\text { araştırma deseni kullanılmıştır. Araştırmada literatür taraması yapılarak nitel } \\
\text { veri toplama aracı olan yarı yapılandırılmış görüşme formu hazırlanmıştır. Nitel } \\
\text { veri toplama aracından ve literatür taramasından elde edilen verilerle nicel veri } \\
\text { toplama aracı olan anket hazırlanmıştır. Araştırmada; öğretmen kariyer } \\
\text { basamakları oluşturulması, öğretmenin mesleki gelişimine katkısının olacağı, } \\
\text { öğretmenin içsel motivasyonuna katkı sunabileceği ortaya çımıştır. Kariyer } \\
\text { basamaklarının yeniden tasarlanarak yasal alt yapısının oluşturulması, } \\
\text { öğretmenin mesleki gelişimine katkı sunabileceği bulgularına ulaşılmıştır. } \\
\text { Ayrıca öğretmen kariyer basamaklarında yükselmede “öğretmenin denetim ve } \\
\text { değerlendirme sonuçları, merkezi sınav sonuçları, yüksek lisans ve doktora } \\
\text { yapması, aldı̆̆ı ödül ve cezaları, teknik, sosyal, kültürel ve sportif becerileri, } \\
\text { yayınları (kitap, makale), kıdem ve çalıştı̆ğ yer, hazırladığı projeleri, katıldığ1 } \\
\text { hizmet içi eğitim kursları, yabancı dil bilmesi” şeklinde kriterler kullanılabilir. } \\
\text { Kariyer basamakları "aday öğretmen, öğretmen, uzman öğretmen ve } \\
\text { başöğretmen” şeklinde kademelendirilebilir. }\end{array}$ \\
\hline
\end{tabular}

1 Bu araştırma Prof. Dr. Murat Gürkan GÜLCAN danışmanlığında yürütülen İzzet KAPLAN'ın doktora tezinden üretilmiştir.

Kaplan, İ., \& Gülcan, M. G. (2020). Öğretmen kariyer basamaklarının oluşturulmasına ilişkin görüşlerin incelenmesi: karma yöntem araştırması. Gazi Eğitim Bilimleri Dergisi, 6(3), 380-406.

DOI: https://dx.doi.org/110.30855/gjes.2020.06.03.007

Dergi Web Sayfası: http://dergipark.gov.tr/gebd 


\section{Examining the Views on the Formation of Teacher Career Ledders: Mixed Method Research}

\begin{tabular}{|c|c|}
\hline Article Info & ABSTRACT \\
\hline $\begin{array}{l}\text { Keywords: } \\
\text { Career ladder, } \\
\text { Education } \\
\text { supervisor, } \\
\text { School principal, } \\
\text { Teacher } \\
\text { professional } \\
\text { development, } \\
\text { Student } \\
\text { achievement }\end{array}$ & $\begin{array}{l}\text { The aim of this study is to determine the opinions of maarif inspectors, } \\
\text { school principals and teachers on the creation of teacher career steps in } \\
\text { Turkey. In this research, it has been tried to determine the creation of } \\
\text { career ladder, whether it can be a catalyst that can provide significant } \\
\text { improvements in the professional development of the teacher. } \\
\text { According to the opinions of teachers, school administrators and } \\
\text { education inspectors; Answers were sought for the questions of "The } \\
\text { effect of creating career ladder on teacher professional development, } \\
\text { how to form career ladder, which criteria should be used in promoting } \\
\text { teacher career ladder, how to benefit from a teacher at upper career } \\
\text { ladder". Mixed research design was used in the research. A semi- } \\
\text { structured interview form, which is a qualitative data collection tool, } \\
\text { was prepared by scanning the literature in the research. The } \\
\text { questionnaire, which is a quantitative data collection tool, was prepared } \\
\text { with the data obtained from the qualitative data collection tool and the } \\
\text { literature review. In the study; It was revealed that establishing teacher } \\
\text { career ladder would contribute to the professional development of the } \\
\text { teacher and contribute to the inner motivation of the teacher. It was } \\
\text { reached the findings that redesigning career steps and establishing the } \\
\text { legal infrastructure can contribute to the professional development of } \\
\text { the teacher. In addition, in promoting the teacher career ladder, "teacher } \\
\text { supervision and evaluation results, central examination results, master's } \\
\text { and doctorate degrees, awards and penalties, technical, social, cultural } \\
\text { and sporting skills, publications (book, article), seniority and work, in-service training courses attended, foreign language } \\
\text { knowledge" can be used. Career ladders can be staged as "prospective } \\
\text { teachers, teachers, expert teachers and head teachers". }\end{array}$ \\
\hline
\end{tabular}

\section{GİRIş}

Bilgi ve teknolojideki hızlı değişim bütün sistemleri olduğu gibi eğitim sistemini ve özelde, öğretmeni değişme ve gelişmeye zorlamaktadır. Bu değişme ve gelişmeler, öğretmenin üniversitelerde öğrendiği bilgilerin kısa sürede geçerliliğini kaybetmesine sebep olmaktadır. Başka bir deyişle değişme ve gelişme hızına uyum sağlamayan öğretmenin niteliğinin sorgulanmasına ve en sonunda sistemin dışına itilmesine neden olabilir. Gelecekte, bilimsel ve teknolojik gelişme ve değişme hızını yakalayabilen öğretmenlere ihtiyaç duyulmaktadır. Bu çerçevede öğretmenin sürekli meslekî gelişimlerinin sağlanması geleceğin en önemli çalışma alanı haline geldiği söylenebilir. Öğretmenin sürekli mesleki gelişiminde üniversitelere, eğitim 
yönetimi ve denetimine, öğretmenin kendisine bazı sorumluluklar ve yükümlülükler düşmektedir.

Öğretmenin sürekli mesleki gelişiminde birinci görev, kuramsal ve uygulama eğitimlerinin alındığı üniversitelere düşmektedir. Üniversitelerin öğretmen yetiştiren bölümleri bilimsel gelişmelere paralel olarak, öğretmenin “öğrenmeyi öğrenen” bir anlayışla öğrencilerini yetiştirmesi gereksinmesi ortaya çıkmaktadır. Öğretmen yetiştiren bölümler, üst sistemlerdeki değişimlere paralel olarak, yasal metinleri yakından takip etmeleri ve bu değişimlere göre kendilerini sürekli güncellemeleri gerekmektedir.

Öğretmenin mesleki gelişiminde ikinci görev eğitim yönetimi ve denetimine düşmektedir. Eğitim yönetimi ve denetimi, eğitim sisteminin alt sistemidir ve öğretmenin mesleki gelişiminin sürekliliğinin sağlanmasında yasal sorumludur. Eğitim yönetimi ve denetimi öğretmenin niteliğinin geliştirilmesi yolu ile öğrenci başarısını artırmayı hedeflemektedir. Başka bir deyişle mesleki gelişimi öğretmen kalitesi ile ilişkilendirmek, öğrenci başarısı ile sonuçlanacaktır (Sullivan ve Glanz, 2015). Bu amaçla yönetim tarafından öğretmenin mesleki çalışmalarının durumun saptanması, değerlendirmesi, düzeltme ve geliştirmesini içerisine alan bir dizi çalışmaların yapılması gereksinimi ortaya çıkmaktadır (Başar, 1993).

Öğretmenin sürekli mesleki gelişiminde üçüncü görev öğretmenin kendisine düşmektedir ve içsel etkiye sahiptir. Bu içsel etki her öğretmende farklı düzeyde olabilir. Bu içsel etkinin öğretmenin mesleğine yüklediği anlamla ilgili olduğu söylenebilir. Öğretmen mesleğini severek yapıyor, bundan haz duyuyorsa bu etkinin arttığını, tersi olduğu durumda ise etkinin azaldığ1 söylenebilir. $\mathrm{Bu}$ düşünce öğretmenin içsel motivasyonu olarak adlandırılabilir. Öğretmenin çalışma ve başarısının takdir edilmesi, ödüllendirilmesi, motivasyonunu olumlu etkileyebilir. Bu içsel motivasyon, öğretmen kariyer basamakları oluşturularak somut hale getirilebilir. Öğretmen kendi başarı ve çalışmalarına göre bir üst kariyer basamağına çıkarak öğrenmeye, kendini geliştirmeye güdülenebilir.

Öğretmenlik mesleği; 1739 sayılı Milli Eğitim Temel Kanunu'nun 43. Maddesinde, devletin eğitim, öğretim ve bununla ilgili yönetim görevlerini üzerine alan özel bir ihtisas mesleği olarak tanımlanmıştır. Bu ihtisas mesleğine başlayan bir öğretmen emekli olana kadar öğretmen olarak görev yapmaktadır. Bu durum öğretmenlerin motivasyonunu artırmadığı, öğretmenin mesleki gelişimine olumsuz etkisi olduğu gerekçeleriyle öğretmen kariyer basamakları oluşturulması söylenegelmiştir. Yapılan araştırmalarda, gelişmiş ve gelişmekte olan ülkelerde bulunan öğretmenlerin önde gelen problemi motivasyon eksikliği olarak ortaya çıkmıştır (Crehan, 2016). Öğretmen kariyer basamaklarının oluşturulması öğretmenin mesleki gelişiminde motivasyon sağlayan bir güç olup olmayacağı bu çalışmada tartışılmıştır. 
Türkiye'de Milli Eğitim Bakanlığı (MEB, 2014) tarafından 2005 yılında, 1739 sayılı Milli Eğitim Temel Kanunun 43. Maddesinde; “Öğretmenlik mesleği; adaylık döneminden sonra öğretmen, uzman öğretmen ve başöğretmen olmak üzere üç kariyer basamağına ayrılır." şeklinde kanun değişikliği yapılarak öğretmen kariyer basamaklarını oluşturulmuştur. Kanundan sonra MEB tarafından 2005 yılı içerisinde kabul edilen ve Resmi Gazete' de yayımlanan "Öğretmen Kariyer Basamaklarında Yükselme Yönetmeliği" hazırlanmıştır. 2006 yılında yapılan bir sınavdan başarılı olanlar (106,536 öğretmen) uzman öğretmen olarak atanmıştır. Uzman öğretmenlik sınavı bir kez uygulanırken, başöğretmenlik sınavı hiç yapılmamıştır. Kariyer basamaklarına karşı olan sendika ve gruplar tarafından yönetmeliğin iptali için mahkemeye başvurulmuştur. Sonuç olarak Danıştay kararı ile "Öğretmen Kariyer Basamaklarında Yükselme Yönetmeliği" uygulaması iptal edilmiştir. Kariyer basamakları ile ilgili kanun yürürlükte olduğu halde uygulanmamaktadır.

"Kariyer, Latince "carrus" at arabası ve "carrera" (yol), Fransizca "Carrierre" (yarış yolu), İngilizce "Career" (meslek) kelimelerinden gelmektedir. Geçmiş yüzyıllarda at arabasının arkasında bıraktığı iz anlamına gelen bu kelime, artık bir kişinin iş alanında sürekli ilerlemesi anlamında kullanılmaktadır (Taşkaya, 2007). Adal'den aktaran Dağlı'ya (2007) göre kariyer, bir insanın çalışabileceği yıllar boyunca, herhangi bir iş alanında adım adım ve sürekli olarak ilerlemesi, deneyim ve yetenek kazanması anlamına gelir. Kariyer çalışanın çalışmada gösterdiği başarı doğrultusunda yükselmesi olarak tanımlanabilir. Başka bir deyişle, kariyer bir kişinin iş yaşamında sahip olmak ve ulaşmak isteyeceği uzmanlık ve iş başarısıdır. İnsan kaynakları yönetiminin personeli yalnızca işe alırken bilgi ve yeteneğe göre seçim yapması yeterli olmayıp, ayrıca bu yetenekli kişileri örgütte tutabilmesi gerekir (Dağlı, 2007). Kariyer yetenekli kişileri meslekte tutmasına yardımcı olurken, mesleki gelişim isteyen çalışanlar için motivasyon kaynağı olduğu söylenebilir.

Kariyer basamaklarının gerekçelerini; Çakıroğlu (2005), öğretmenlerin performansının artırılması; Deniz (2009), eğitim sistemini çağdaş bir yapıya kavuşturma arayışı, öğretmenlerin statülerinin iyileştirilmesi, öğretmenlerin mesleki ve kişisel gelişimlerinin sağlanması, görevlerinin önemi, güçlüğü ve sorumluluklarına bağlı olarak öğretmenlere gerekli itibar sağlanması, olarak sıralarken; Demir (2011), öğretmenlik mesleğindeki kalitenin yükseltilmesini sağlamak, öğretmenleri araştırma ve incelemeye yönlendirerek meslekleri ile ilgili yeni gelişmeleri takip etmelerini teşvik etmek, öğretmenin eğitim sistemindeki işlev ve verimliliğini arttırmak ve meslekî tükenmişliği engellemek olarak açıklamıştır. Kariyer basamaklarının oluşturulmasının gerekçesi kısaca; öğretmenin mesleki ve kişisel gelişimlerinin sağlanmasında teşvik edici bir statü artışıdır denilebilir. 
Türkiye'de öğretmen kariyer basamakları ile ilgili yapılan çalışmalar, yasal değişikliğin yapıldığı 2005 yılını takip eden yıllarda yapılmıştır. Bu çalışma yasanın çıkmasından bu yana geçen 14 yıl sonra yapılması sebebiyle, öğretmen kariyer basamaklarının oluşturulmasına karşı tutumları belirlemek açısından büyük önem arzetmektedir. Süreç içesinde yaşanan değişimlere paralel olarak, kariyer basamaklarının oluşturulmasına ilişkin yeni araştırmaların yapılması gerektiği ortaya çıkmaktadır. Bu çalışma ile Türkiye'de öğretmen kariyer basamaklarının oluşturulmasına ilişkin maarif müfettişleri, okul müdürleri ve öğretmenlerin görüşlerini belirlemek amaçlanmıştır. Kariyer basamaklarının oluşturulması, öğretmenin mesleki gelişiminde önemli gelişmeler sağlayabilecek bir katalizör olup olamayacağı bu araştırmada ortaya konulmaya çalışılmıştır.

\section{Araştırmanın Amacı}

$\mathrm{Bu}$ araştırmanın genel amacı, Türkiye'de öğretmen kariyer basamaklarının oluşturulmasına ilişkin maarif müfettişleri, okul müdürleri ve öğretmenlerin görüşlerini belirlemektir. Bu amaç doğrultusunda aşağıdaki alt amaçlar belirlenmiştir.

a) Öğretmen kariyer basamakları oluşturulmasının öğretmenin mesleki gelişimine etkileri nedir?

b) Öğretmen kariyer basamaklarında yükselmede kullanılabilecek olası kriterler nelerdir?

c) Öğretmen kariyer basamakları ne şekilde oluşturulabilir?

d) Öğretmen kariyer basamaklarında üst kariyerde bulunan öğretmenlerden nasıl yararlanılabilir?

\section{YÖNTEM}

Araştırma betimsel tarama modelinde olup, karma araştırma deseni kullanılmıştır. "Karma yöntem araştırması bir tek araştırmada veya yakın ilişkili çalışma dizisinde nicel ve nitel verilerin veya tekniklerin birleştirildiği veya karıştıııldığı araştırma yaklaşımıdır." (Christensen, Johnson \& Turner, 2015, s. 423). İsimlendirmesi de NITEL $\rightarrow$ NiCEL şeklindedir. Her iki yönteminde büyük harfle yazılması araştırma verisinin eşit statüde değerli olduğunu, okun yönü de önce nitel araştırma verileri, daha sonra nicel araştırma verilerinin elde edilmesini göstermektedir. Araştırmada Creswell (2003; 2015)'in sınıflandırdı̆̆ı̆, keşfedici sıralı desen kullanılmıştır. Keşfedici Sırah Desende: İlk aşamada nitel veriler toplanır, ikinci aşamada nicel veriler toplanır ve analiz edilir. Öğretmen kariyer basamaklarını oluşturma çalışması, öğretmenlerin sürekli mesleki gelişimini destekleyen denetim modeli (ÖSMG) isimli araştırmanın bir bölümünü oluşturmaktadır. Araştırma verileri 2018-2019 öğretim yılında elde edilmiştir. 


\section{Çalışma Grubu}

Araştırmanın nitel verileri için: Araştırmada "amaçlı örnekleme yöntemlerinden" "maksimum çeşitlilik örneklemesi" kullanılmıştır. Maksimum çeşitlilik örneklemesi; göreli olarak küçük bir örneklem oluşturmak ve bu örneklemde çalışılan probleme taraf olabilecek bireylerin çeşitliliğini maksimum derecede yansıtmaktır (Yıldırım \& Şimşek, 1999, s. 70). Örneklem seçmede sosyo-ekonomik düzey, şehir merkezi, ilçe merkezi, belde ve köyde olma durumu, öğretmenlerin branşlarına göre farklı özellikte (çeşitlikte) olması sağlanmıştır. Çalışma grubunda; 21 maarif müfettişi ile Hatay ilinde görev yapan 20 okul yöneticisi, 20 branş öğretmeni, 20 sınıf öğretmeninden oluşmaktadır. Öğretmenlerin 23'ü kadın, 17'si erkek, okul yöneticilerinin 2'si kadın, 18'i erkek, maarif müfettişlerinin 2'si kadın, 19'u erkek olduğu, toplamda katılımcıların 27'si kadın, 54'ü erkek olduğu görülmektedir. Öğretmenlerde kadın erkek dengeli dağllırken, okul yöneticileri ve maarif müfettişlerinin çoğunluğu erkeklerden oluşmaktadır. Okul yöneticiliği ve maarif müfettişliğinin kadınlar açısından tercih edilmeyen bir meslek olduğu söylenebilir. Öğrenim durumu ile ilgili değerlendirmede, katılımcıların; 7'sinin ön lisans, 4' ünün lisans tamamlama, 62'sinin lisans, 7'sinin yüksek lisans, 1'inin doktora mezunu olduğu, görülmektedir. Branşlara göre yapılan değerlendirmede, katılımcıların 48' inin sınıf öğretmeni, 5' inin Matematik, 4' ünün Türkçe, 4' ünün Sosyal Bilgiler, 2' sinin Fen Bilimleri, 4' ünün İngilizce, 3' ünün Güzel Sanatlar branşunda olduğu görülmektedir. Katılımcıların yoğunluklu olarak sınıf öğretmeni olduğu, bunun nedeninin de okul yöneticileri ve maarif müfettişlerinin sınıf öğretmeni olmalarından kaynaklı olduğu söylenebilir.

Araştırmanın nicel verileri için: Araştırmanın nicel bölümünde seçkisiz örnekleme yöntemlerinden, tabakalı örnekleme yöntemine uygun biçimde okul yöneticileri ve öğretmenler çalışma grubu olarak belirlenmiştir. "Tabakalı örnekleme, evrendeki alt grupların belirlenip bunların evren büyüklüğü içindeki oranlarıyla örneklemde temsil edilmelerini sağlamayı amaçlayan örnekleme yöntemi" olarak tanımlanmıştır (Büyüköztürk vd., 2013, s. 86). Çalışma grubuna seçilen okul yöneticileri ve öğretmenler; okulların bulunduğu çevrenin sosyo ekonomik düzeyi, okulların köy, belde, ilçe ve il merkezinde bulunma durumu, sınıf öğretmeni ve branş öğretmeni olma gibi değişkenlere göre belirlenmiştir. Tabakalı örnekleme uygun olarak, Hatay ilinde toplam 36 okulda görev yapan okul yöneticisi, öğretmenlerden gönüllü olarak; “Öğretmenin Sürekli Mesleki Gelişimini Destekleyen Denetim Modeli” anketini doldurmak isteyenlere anket uygulanmıştır. Belirlenen okullardaki yaklaşık 1000 öğretmen ve okul yöneticisinden, 348'i ve 65 maarif müfettişi anketi doldurmayı kabul etmiştir. Toplam 413 anketin 41'i yanlış, eksik doldurma nedeniyle ayrılarak, 372 anket geçerli kabul edilmiştir. 


\section{Veri Toplama Aracının Geliştirilmesi ve Veri Toplama Aracı}

Araştırmanın nitel verileri için: Öğretmen kariyer basamaklarını oluşturma çalışması, ÖSMG isimli araştırmanın bir bölümünü oluşturmaktadır. Veri toplama aracının geliştirilmesi; öğretmenin mesleki gelişimi ve denetim modelleri ile ilgili alan taraması yapıldı. Bu alan taramasına dayalı olarak yarı yapılandırılmış görüşme formu soruları hazırlandı. Yarı yapılandırılmış görüşme formu uzman görüşlerine sunuldu. Eğitim yönetimi ve denetimi alanında görevli 5 öğretim üyesinden uzman görüşleri alındı. Uzman görüşleri doğrultusunda soru sayısında ve köklerinde düzeltme yapıldı. Yarı yapılandırılmış görüşme formu 2 müfettiş, 2 okul müdürü, 2 öğretmenle yüz yüze görüşme yapılarak pilot uygulaması yapıldı. Pilot uygulama ve uzman görüşlerinden elde edilen bilgilere göre yarı yapılandırılmış görüşme formu soru sayısı 8 olarak belirlenmiştir. Bu sorulardan 1'i ve üç sonda sorusu öğretmen kariyer basamaklarının oluşturulması ile ilgilidir. Öğretmen kariyer basamakları oluşturulmasının öğretmenin mesleki gelişimine etkileri nedir? Öğretmen kariyer basamaklarında yükselmede kullanılabilecek olası kriterler nelerdir ?, Öğretmen kariyer basamakları ne şekilde oluşturulabilir ? ve Öğretmen kariyer basamaklarmda üst kariyerde bulunan öğretmenlerden nasıl yararlanilabilir? Açıklayınız." şeklindedir. Bu araştırmada, veriler bireysel görüşme kullanılarak toplanmıştır. Görüşmeler katılımcılardan izin alınarak kayıt cihazına kayıt edilmiştir. Görüşmede anlaşılmayan hususlarla ilgili görüşmecilere, "örnek verir misiniz", "neden böyle düşünüyorsunuz", "açıklama getirir misiniz” gibi müdahaleler yapılmıştır.

Güvenirlik ve geçerlilik kapsamında araştırma yönteminin iyi belirlenmesi; araştırma yapılacak kurumun veya ortamın iyi tanınması, araştırma ortamında yeterince bulunulması, çalışma grubunun amaçlı örnekleme yöntemlerinden maksimum çeşitlilik örneklemesi yöntemiyle belirlenmesi, katılımcıların gönüllülük esasına göre seçilmesi, yöntem ve toplanan verilerin tekrar tekrar gözden geçirilmesi, uzman ve meslektaş görüşlerinin alınması, çeşitli veri kaynaklarının karşılaştırılması, ses kayıtlarının yapılması, veriler başkalarının incelemesi için uygun biçimde saklanması ve kaynakça yeterliliğinin sağlanması çalışmaları yapılmıştır. Dış güvenirlik araştırmanın veri kaynakları olan maarif müfettişleri, okul yöneticileri, sınıf ve branş öğretmenleri tanımlanmış, veri toplama ve analiz yöntemleri de ayrıntılı olarak açıklanmıştır.

Araştırmanın nicel verileri için: Nitel yöntemle elde edilen verilerden ve literatür taramasından elde edilen verilerle ÖSMG anketi soruları (maddeleri) oluşturuldu. Pilot uygulama ve uzman görüşlerinden elde edilen bilgilerle ankete son şekli verilmiştir. ÖSMG anketinin 65 sorusunun küçük bir kısmı, öğretmen kariyer basamaklarının oluşturulması ile ilgilidir. 


\section{Verilerin Analizi}

Araştırmanın nitel verileri için; Çalışmada elde edilen verilerin analizinde, betimsel analizden daha derin analiz biçimi olan "içerik analizi" tekniğinden yararlanılmıştır. Öğretmenlerin Sürekli Mesleki Gelişimini Destekleyen Denetim Modelinde veriler; 4 aşamada analiz edilmiştir. 1. Adlandırma, kodlama ve çıkarma, 2. Tema geliştirme, 3. Geçerlik ve güvenirlik sağlama, 4. Raporlaştırma aşamalarından oluşmaktadır. Veriler katılımcılara, sınıf öğretmeni S, Branş öğretmeni B, Yönetici Y, Müfettiş M (M1... M21, Y1 ...Y20, S1, ...S20, B1...B20) şeklinde kodlar verilmiştir. Katılımcılardan elde edilen görüşlerden, kodlar oluşturulmuş, kodlardan kategori ve temalar oluşturularak, doğrudan katılımcı görüşleri ile yorumlanmıştır.

Araştırmanın nicel verileri için: Nitel yöntemle elde edilen verilerden ve literatür taramasından elde edilen verilerle “Öğretmenin Sürekli Mesleki Gelişimini Destekleyen Denetim Modeli" anketi soruları (maddeleri) oluşturuldu. Pilot uygulama ve uzman görüşlerinden elde edilen bilgilerle ankete son şekli verilmiştir. Nicel verilerin analiz edilmesi amacıyla, sosyal bilimler için istatistik paket (SPSS) programından yararlanılmıştır Anket sorularının ayrı ayrı ki kare (kaykare) hesaplaması, frekans ve yüzdeleri hesaplaması, aritmetik ortalama alınarak değerlendirilmiştir. Küçük bir gruptan elde edilen nitel veriler, büyük bir gruptan elde edilen nicel veriler test edilerek değerlendirilmiştir.

\section{BULGULAR}

$\mathrm{Bu}$ bölümde araştırmada elde edilen bulgulara ait sonuçlar, alt problemler altında incelenmiştir.

a) Kariyer Basamakları Oluşturulmasının Öğretmenin Sürekli Mesleki Gelişimine Etkileri Nedir? Alt amacına ilişkin bulgular.

Öğretmen Kariyer Basamaklarının oluşturulmasının öğretmenin mesleki gelişimine katkısına ilişkin soruya verilen cevaplar Tablo 1'de özetlenmiştir.

Tablo 1.

Katılımcıların, Öğretmen Kariyer Basamaklarının Oluşturulmasına İlişkin Görüşleri

\begin{tabular}{|c|c|c|c|c|c|c|}
\hline & Sinıf Öğr & Branş Öğr & Yönetici & Müfettiş & (f) & $\%$ \\
\hline Olumlu & $\begin{array}{c}\text { S1, S4, S8, S9, S10, } \\
\text { S11, S12, S13, S14, } \\
\text { S15, S16, S17, S18, } \\
\text { S19, S20 }\end{array}$ & $\begin{array}{c}\text { B1, B2, B4, B6, B7, } \\
\text { B9, B10, B11, B12, } \\
\text { B13, B14, B15, B16, } \\
\text { B17, B18, B19, B20 }\end{array}$ & $\begin{array}{c}\text { Y1, Y2, Y3, Y4, Y5, } \\
\text { Y6, Y7, Y9, Y10, } \\
\text { Y11, Y12, Y13, } \\
\text { Y14, Y15, Y16, } \\
\text { Y17, Y18, Y19, Y20 }\end{array}$ & $\begin{array}{l}\text { M1, M2, M3, M5, M6, } \\
\text { M7, M8, M9, M11, } \\
\text { M12, M13, M14, M15, } \\
\text { M16, M17, M18, M19, } \\
\text { M20, M21 }\end{array}$ & & \\
\hline (f) & 15 & 17 & 19 & 19 & 70 & 87 \\
\hline Olumsuz & S2, S3, S5, S6, S7 & B5, B8 & $\mathrm{Y} 8$ & M4, M10 & & \\
\hline (f) & 5 & 2 & 1 & 2 & 10 & 12 \\
\hline Kismen & & B3 & & & & \\
\hline (f) & & 1 & & & 1 & 1 \\
\hline
\end{tabular}


Nitel verilere göre: Tablo 1 incelendiğinde; katılımcılar, öğretmen kariyer basamaklarının oluşturulmasına 81 katılımcının, 70'i olumlu (\% 87), 10'i olumsuz (\%12), 1'i ise kısmen olumlu (\% 1) olarak değerlendirmiştir. Kariyer basamaklarının oluşturulması konusunda sınıf öğretmenlerinin 15'i olumlu, 5'i olumsuz, branş öğretmenlerinin 17'si olumlu, 2'si olumsuz, 1'i kısmen olumlu, okul yöneticilerinin $19^{\prime} u$ olumlu, 1'i olumsuz, müfettişlerin 19'u olumlu, 2'si olumsuz görüş belirtmiştir. Toplamda 81 katılımcının 70'i olumlu, 1'i ise kısmen olumlu değerlendirilerek (\% 88), kariyer basamaklarının oluşturulmasının öğretmenin mesleki gelişimine katkısı olduğu yönünde görüş belirtmişlerdir. Öğretmen kariyer basamaklarmın oluşturulması katılımcılarının çoğunluğu ( $f=70 ; \%$ 87) tarafindan benimsendiği söylenebilir. Katılımcılardan 10'u kariyer basamaklarının oluşturulmasına karşı çıkmıştır. Katılımcıların çoğunluğunun kariyer basamaklarının oluşturulmasına olumlu baktığı sonucuna ulaşılmıştır. Tablo 2'de katılımcıların öğretmen kariyer basamakları oluşturulmasının gerekçeleri temalar ve kategoriler halinde sunulmuştur.

Tablo 2

Katılımcılar, Öğretmen Kariyer Basamaklarının Oluşturulmasına İlişkin Gerekçeleri

\begin{tabular}{llc}
\hline Tema & Kategori & f \\
\hline & Geliştirme aracı olması & 30 \\
& Öğretmen gelişimin tetikleyen süreç olması & 11 \\
& Maddi getiri olması durumda etkili olması & 11 \\
\multirow{4}{*}{ Olumlu gerekçeler } & Belirli aralıklarla tekrar etmesi & 5 \\
& Öğretmen performansının nesnel olarak ölçülmesi & 4 \\
& Çalışana ödül olması & 3 \\
\cline { 2 - 3 } & Toplam & 64 \\
\hline \multirow{4}{*}{ Olumsuz gerekçeler } & Mesleki gelişime etkisi olmayacağı & 10 \\
& I̧ş barışını bozacağı & 8 \\
& Öğretmenlik mesleğinin gönül işi olması gerektiği & 2 \\
\cline { 2 - 3 } & Toplam & 20 \\
\hline
\end{tabular}

Tablo 2 incelendiğinde; katılımcıların, öğretmen kariyer basamaklarmın oluşturulmasına ilişkin "Olumlu gerekçeler" ( $f=64$ ) teması altında "geliştirme aracı olması" ( $\mathrm{f}=30$ ), "öğretmen gelişimini tetikleyen bir süreç olması" ( $\mathrm{f}=11$ ), "maddi getiri olması durumunda etkili olması" ( $\mathrm{f}=4$ ), "belirli aralıklarla tekrar etmesi” (f=5), "öğretmen performansının nesnel olarak ölçülmesi” ( $f=4)$, "çalışana ödül olması" ( $\mathrm{f}=3$ ) şeklinde altı (6) kategoride toplanmışır. Bu tema altındaki örnek görüşler şu şekildedir: “...Kariyer basamakları oluşturulması, öğretmenin kendini geliştirmesini destekleyici bir yol olabilir...” (S4), “...Kariyer basamakları oluşturulurken maddi getirisi oluşturulursa etkili olur..." (B16, Y2), “...Her beş yılda uzman öğretmenlik ve başöğretmenlik yeniden değerlendirilmelidir." (M12), “...Kendini geliştiren öğretmenin teşvik edilmesi anlamına gelir. MEB tarafindan geç kalmış bir çalışmadır. Bir an önce öğretmen kariyer basamaklarn oluşturulmalıdır. Bu durum öğretmeni bir toplumsal baskı gibi kendini geliştirmeye zorlayacaktır." (Y4)

Katılımcıların öğretmen kariyer basamaklarının oluşturulmasına ilişkin "Olumlu gerekçeler" temasında: öğretmen kariyer basamaklarının oluşturulması; öğretmeni geliştirme 
aracı olabileceği, öğretmen gelişimini tetikleyen bir süreç olabileceği, maddi getiri olması durumunda etkili olabileceği, değerlendirmenin belirli aralıklarla tekrar edilmesinin öğretmenin mesleki gelişiminin sürekliliğini sağlayacağı, öğretmen performansının nesnel olarak ölçülmesine yardımcı olacağı, çalışana ödül olarak düşünülebileceği görüşleri öne çıkmaktadır. Katılımcılar öğretmen kariyer basamaklarını öğretmeni geliştirme süreci olarak algıladıkları söylenebilir.

Katılımcıların, öğretmen kariyer basamaklarının oluşturulmasına ilişkin "Olumsuz gerekçeler" $(f=20)$ teması altında: öğretmen kariyer basamakları oluşturmanın; "mesleki gelişime etkisi olmayacağı" ( $\mathrm{f}=10)$, "iş barışını bozacağı" $(\mathrm{f}=8)$, "öğretmenlik mesleğinin gönül işi olması gerektiğì" (f=2) şeklinde üç kategoride toplanmıştır. Bu tema altındaki örnek görüşler şu şekildedir: “...Kariyer basamaklar öğretmenin mesleki gelişimine etkisi olmaz." (S7, B3, Y8, M4), “... Öğretmenler arasında ast üst ilişkisi ortaya çıkabilir." (S6), “...Kariyer basamakları oluşturmanın okuldaki iş başarısını bozacă̆ını düşünmüyorum." (S4), “...̈̈̆gretmenler arasında iç karışıklılara neden olabilir. Veli ben çocuğumu uzman öğretmene vermek istiyorum diye başvurursa sorunlar olabilir. Uzman öğretmenler başka bir okulda toplanırsa bu sorun aşılabilir." (S13), “...Ben öğretmenliğin bir gönül işi olduğunu, aşk işi olduğunu düşünüyorum. Kariyer basamaklarn işin içine girerse öğretmenlik maddesel hale gelebilir." (B8),

Katılımcıların, öğretmen kariyer basamaklarının oluşturulmasına ilişkin “Olumsuz gerekçeler" temasında: öğretmen kariyer basamakları oluşturmanın; öğretmeni mesleki gelişime etkisi olmayacağını, iş barışını bozacağını, öğretmenlik mesleğinin gönül işi olması gerektiği belirtilmiştir. Katılımcıların çok azı, öğretmen kariyer basamaklarının oluşturulmasının öğretmen gelişimine etkisi olmayacağını belirtmişlerdir.

Nicel verilere göre; ÖSMG anketinin 1, 2, 3, maddeleri öğretmen kariyer basamaklarının oluşturulması ile ilgilidir. Tablo 3 'te öğretmen kariyer basamaklarının isimlendirilmesine ilişkin sorunun frekans, yüzde, ki kare sonuçları verilmiştir.

Tablo 3.

Katıllmcıların, "Aday öğretmen, öğretmen, uzman öğretmen, başöğretmen biçiminde kariyer basamakları ve özlük hakları oluşturulur." Sorusuna Verdikleri Cevapların Frekans, Yüzde ve Ki Kare Sonuçları

\begin{tabular}{|c|c|c|c|c|c|c|c|c|}
\hline & & & $\begin{array}{c}\text { Hiç } \\
\text { katılmıyorum }\end{array}$ & $\begin{array}{c}\text { Az } \\
\text { katılıyorum }\end{array}$ & $\begin{array}{l}\text { Orta düzeyde } \\
\text { katılıyorum }\end{array}$ & $\begin{array}{c}\text { Büyük } \\
\text { ölçüde } \\
\text { katılıyorum }\end{array}$ & $\begin{array}{c}\text { Tamamen } \\
\text { katılıyorum }\end{array}$ & Toplam \\
\hline \multirow{6}{*}{ 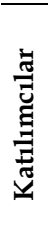 } & \multirow{2}{*}{ Müfettiş } & $\mathrm{f}$ & 6 & 4 & 4 & 19 & 32 & 65 \\
\hline & & $\%$ & $9,2 \%$ & $6,2 \%$ & $6,2 \%$ & $29,2 \%$ & $49,2 \%$ & $100,0 \%$ \\
\hline & Okul & $\mathrm{f}$ & 6 & 0 & 1 & 14 & 26 & 47 \\
\hline & Yöneticisi & $\%$ & $12,8 \%$ & $0,0 \%$ & $2,1 \%$ & $29,8 \%$ & $55,3 \%$ & $100,0 \%$ \\
\hline & & $\mathrm{f}$ & 71 & 25 & 58 & 53 & 53 & 260 \\
\hline & Ogretmen & $\%$ & $27,3 \%$ & $9,6 \%$ & $22,3 \%$ & $20,4 \%$ & $20,4 \%$ & $100,0 \%$ \\
\hline \multirow{2}{*}{\multicolumn{2}{|c|}{ Toplam }} & $\mathrm{f}$ & 83 & 29 & 63 & 86 & 111 & 372 \\
\hline & & $\%$ & $22,3 \%$ & $7,8 \%$ & $16,9 \%$ & $23,1 \%$ & $29,8 \%$ & $100,0 \%$ \\
\hline \multicolumn{4}{|c|}{ Pearson Ki-kare } & $\begin{array}{c}\text { Değer } \\
58,785^{a}\end{array}$ & $\begin{array}{c}\text { sd } \\
8\end{array}$ & & $\begin{array}{c}\mathbf{p} \\
, 000\end{array}$ & \\
\hline
\end{tabular}


ÖSMG anketinin "Aday öğretmen, öğretmen, uzman öğretmen, başöğretmen biçiminde kariyer basamakları ve özlük hakları oluşturulur" sorusuna müfettiş ve okul yöneticilerinin cevaplarının birbirlerine benzer oldukları, ancak öğretmenlerin cevaplarının farklılaştığı anlaşılmaktadır. Bu ifadenin "hiç katılmama" ve "az katılma" seçeneklerine müfettişler ve okul yöneticileri \% 10-\% 6 arasında katılırken öğretmenlerin \% 38 'i bu seçeneklerde görüş bildirmişlerdir. Yapılan ki-kare analizinde de bu üç gruba göre bu ifadeye katılma dereceleri arasında fark olduğu anlaşılmaktadır. Hesaplanan ki-kare değeri $(58,785)$ 0,05 manidarlık düzeyinde anlamlı bulunmuştur. Katılımcıların verdiği cevapların toplamına bakıldığında; hiç katılmıyorum 83 (\%22,3), az katılıyorum 29 (\%7,8), orta düzeyde katılıyorum 63 (\%16,9), büyük ölçüde katılıyorum 86 (\% 23,1), tamamen katılıyorum 111 (\%29,8)'dur. Bu soruya; araştırmaya katılan 372 kişinin 289'u $(\% 77,7)$ tarafından kabul görmüştür.

Araştırmamızda elde edilen bulgulara göre; Öğretmen kariyer basamaklarında yükselmek için göstereceği çaba ile mesleki anlamda gelişimine önemli katkllar sunabileceği yönünde değerlendirme yapılmıştır. Kariyer basamaklarının yeniden tasarlanarak, yasal altyapısının oluşturulması öğretmenin mesleki gelişimine katkı sunabilir şeklinde çıkarıma ulaşılmışıı. Bulgular araştırmanın nitel bulguları ile nicel bulgularını tutarl olduğunu göstermektedir.

Katılımcıların, öğretmen kariyer basamaklarının oluşturulmasına ilişkin "Olumlu gerekçeleri"; öğretmeni geliştirme aracı olabileceği, öğretmen gelişimini tetikleyen bir süreç olabileceği, maddi getiri olması durumunda etkili olabileceği, şeklinde görüşler öne çıkarken, "Olumsuz gerekçeler"; kariyer basamakları oluşturmanın öğretmenin mesleki gelişimine etkisi olmayacağını, iş barışını bozacağını, öğretmenlik mesleğinin gönül işi olması gerektiği yönünde görüşler öne çıkmıştır.

\section{b. Öğretmen Kariyer Basamaklarının Oluşturulmasında Kullanılabilecek Kriterlere İlişkin Bulgular}

Nitel verilere göre; Kariyer basamaklarının oluşturulmasında en önemli sorunlardan birisi hangi kriterlere göre değerlendirme yapılacağıdır. Katılımcılara kariyer basamaklarının oluşturulmasında hangi kriterlerin kullanılabileceği soruldu. Katılımcıların verdiği cevaplar Tablo 4' de aktarılmıştır. 
Tablo 4.

Katılımoların, Öğretmen Kariyer Basamakları Kriterleri

\begin{tabular}{clc}
\hline \multicolumn{1}{c}{ Tema } & \multicolumn{1}{c}{ Kategori } & f \\
\hline & Denetim ve değerlendirme sonuçları & 60 \\
& Merkezi sınav olmalı & 45 \\
& Yüksek lisans doktora & 35 \\
& Objektif kriterler & 33 \\
& Ödül ve cezalar & 25 \\
\multirow{3}{*}{ İstenilen kriterler } & Teknik, Sosyal, kültürel ve sportif beceriler & 24 \\
& Yayınlar (kitap, makale) & 20 \\
& Kıdem ve çalışı̆̆ı̆ yer & 18 \\
& Projeler & 11 \\
& Hizmet içi eğitime katılma & 10 \\
& Yabancı dil & 9 \\
& Eleyici olmayan mülakat & 5 \\
& Milli ve manevi değerler & 4 \\
& Üst kurul tarafından değerlendirme & 4 \\
& Etik kurallar & 2 \\
\cline { 2 - 3 } & Toplam & 305 \\
\hline İstenilmeyen kriterler & Mülakat olmamalı & 11 \\
& Merkezi sinav olmamalı & 7 \\
& Ödül ve cezalar objektif verilmiyor & 4 \\
& Kıdem ölçü değil & 3 \\
\cline { 2 - 3 } & Toplam & 35 \\
\hline
\end{tabular}

"İstenilen kriterler" teması ( $f=305)$ altında: Tablo 4 incelendiğinde; Katılımcıların, öğretmen kariyer basamaklarının oluşturulmasında kullanılabilecek kriterler; "İstenilen kriterler" teması ( $f=305)$ altında; "Denetim ve değerlendirme sonuçları" ( $\mathrm{f}=60)$, "Merkezi sinav olmalı" ( $\mathrm{f}=45$ ), “Yüksek lisans doktora" ( $\mathrm{f}=35$ ), “Objektif kriterler" ( $\mathrm{f}=33$ ), “Ödül ve cezalar" ( $\mathrm{f}=25$ ), “Teknik, Sosyal, kültürel ve sportif beceriler" ( $\mathrm{f}=24$ ), "Yayınlar (kitap, makale)" ( $\mathrm{f}=20)$ ), "Kıdem ve çalıştı̆̆ yer" (f=18), "Projeler" (f=11), "Hizmet içi eğitime katılma" ( $f=10)$, "Yabancı dil” (f=9), "Eleyici olmayan mülakat" ( $\mathrm{f}=5$ ), "Milli ve manevi değerler" ( $\mathrm{f}=4$ ), "Üst kurul tarafından değerlendirme" ( $\mathrm{f}=4$ ), "Etik kurallar" ( $\mathrm{f}=2) 15$ kategori oluşturulmuştur. "İstenilmeyen kriterler" ( $f=35)$ teması altında: "mülakat olmamalı" ( $\mathrm{f}=11)$, "merkezi sınav olmamalı" ( $\mathrm{f}=7)$, "ödül ve cezalar objektif verilmiyor" bu nedenle ölçüt olmamalı $(\mathrm{f}=4)$, "kıdem ölçü değil" bu nedenle ölçüt olmamalı ( $\mathrm{f}=3$ ) şeklinde dört kategoride toplanmıştır. Katılımcıların görüşlerine göre, öğretmen kariyer basamaklarının oluşturulmasında, istenilen kriterler 15 başlık altında değerlendirilmiştir.

1. Denetim ve değerlendirme sonuçları $(f=60)$ : Öğretmen kariyer basamaklarının geçişte kullanılacak kriter olarak denetim ve değerlendirmeden elde edilen puanlar en çok atıf alan kriter olmuştur. Öğretmenler denetim ve değerlendirmeden elde edilen puanların kariyer basamaklarında yükselmede kullanması gerektiği ile ilgili örnek görüşler şu şekildedir: “.... Öğretmenin denetimlerinden elde edilen puanları (performansı) değerlendirmede kriter olarak 
kullanılmalıdır." (S1), “... Son beş yılın değerlendirme puanları değerlendirmeye alınmalıdır." (Y14), “... Olumsuz denetim raporu alan öğretmenlerin kariyer ilerlemesi yapılmamalıdır." (B4)

2. Merkezi sınav olmalı ( $f=45$ ): Öğretmen kariyer basamaklarının geçişte kullanılacak kriter ikinci en çok atıf alan kriter, öğretmenlerin merkezi bir sınava tabi tutulması olarak önerilmiştir. Bu kriterle ilgili örnek görüşler şu şekildedir: “...Sınav \% 50 oranında etkilemelidir (sınav artı diğer kriterler)" (B4), "... Öncelikle merkezi stnav ve daha sonra diğer kriterler değerlendirmeye katılmahdır." (Y5), “... En kötü olan sinavda bile objektiflik var. Sinava giren bu sinav sonucuna göre bir adaletin gerçekleştiğini düşünüyor." (M16)

3. Yüksek lisans ve doktora ( $f=35)$ : Öğretmen kariyer basamaklarının geçişte kullanılacak kriterlerden birisi de; öğretmenin Yüksek Lisans ve Doktora eğitimi alması, görülmektedir. Bu kriterle ilgili örnek görüşler şu şekildedir: “...Alanında yüksek lisans yapan öğretmenler direkt olarak uzman öğretmen, alanında doktora yapan öğretmenler direkt başöğretmen yapılabilir..." (M15), "Alanında yüksek lisans ve doktora yapması başöğretmenlikte kullanılabilir" (S17, Y13, Y17)

4. Objektif kriterler ( $f=33)$ : Öğretmen kariyer basamaklarının geçişte kullanılacak kriter olarak sıralanan bir diğer öneri, objektif değerlendirme kriterlerinin oluşturulması olarak sıralanmıştır. Objektif değerlendirme kriterlerinin oluşturulması konusunda katılımcıların kaygıları olduğu ya da kariyer basamaklarının sübjektif değerlendirmeler sonucunda verileceği endişelerinin olduğu söylenebilir. Bu kriterle ilgili örnek görüş şu şekildedir: “...Objektif değerlendirme kriterleri oluşturulmalıdır." (B2, B6, Y3, Y9, M1, M5)

5. Ödül ve cezalar (f=25): Öğretmen kariyer basamaklarının geçişte kullanılacak kriter olarak sıralanan bir diğer öneri, öğretmenin aldığı ödüllerin ve cezaların kariyer basamaklarında yükselmede kullanılmasıdır. Bu kriterde öğretmenin aldığı ödül ve cezalarının kariyer basamaklarında kullanılması önerisi, öğretmenin emeğinin sonuçlarından biri olarak değerlendirildiği şeklinde söylenebilir. Bu kriterle ilgili örnek görüşler şu şekildedir: “...Ödül ve cezalar kriterlerde puan değeri olmalıdı...” (S16, B16, Y5, M7), “... Öğretmenin mesleki ürününün tamamı değerlendirme kriteri olmalıdır..." (B16, B17), “...̈̈̆gretmenin mesleki gelişimi dikkate alınmalıdır..." (S9, Y5, Y15, M5)

6. Teknik, Sosyal, kültürel ve sportif beceriler ( $f=24)$ : Öğretmen kariyer basamaklarının geçişte kullanılacak kriter olarak sıralanan bir diğer öneri, öğretmenin teknik, sosyal, kültürel ve sportif alanda elde etmiş olduğu başarıların öğretmen kariyer basamaklarında yükselmede bir araç olarak kullanılması belirtilmiştir. Bu kriterle ilgili örnek görüşler şu şekildedir: “... Sosyal etkinlikler ve sportif etkinliklerde ki başarıları." (Y6, M19), "... Sanatla uğraşması, enstrüman çalması, sportif faaliyetlerde başarnl olması gibi kriterler kullanılabilir. Avrupa' da öğretmenlerin çok kilolu olmasın istemiyor ve sporla uğraşan öğretmenleri model olduğu için destekliyor. Saz çalan bir öğretmenin ödüllendirilmesi, değerlendirmesi gerekir." (M16) 
7. Yayınlar (kitap, makale) (f=20): Öğretmen kariyer basamaklarının geçişte öğretmenin kitap, makale, dergi vs alandaki yayınları kriter kullanılabileceği belirtilmiştir. Bu kriterle ilgili örnek görüşler şu şekildedir: “...Öğretmenin yaptığı yayınları değerlendirmeye katılmalıdır (Kitap, makale)” (B19, M17), “...Öğretmenin yayınları, kitap, makaleler kriter olmalıdır.” (S13)

8. Kıdem ve çalıştı̆̆ı yer ( $f=18)$ : Öğretmenin kariyer basamağında yükselmesinde, öğretmenin kıdem ve çalıştığı yer de kriter olarak önerilmiştir. Bunun karşısında kıdemin ölçü olamayacağın belirten M13, S17 ve S20 rumuzlu katılımcılar da bulunmaktadır. Bu kriterle ilgili örnek görüşler şu şekildedir: “...Çalışma süresi(kıdem) dikkate alınmalıdır.” (S13. B20, Y2, M7), “... Başöğretmenliğe geçiş için en az 20 yıllık öğretmenlik yapma şartı getirilmelidir.” (Y19), “... Öğretmenin çalıştığı yerler." (M8)

9. Hizmet içi eğitime katılma ( $f=10)$ : Öğretmenin kariyer basamaklarının oluşturulmasında öğretmenin katıldığı hizmet içi eğitimlerinde etkisi olması gerektiği belirtilmiştir. Bu şekilde öğretmenlerin kendilerini geliştirebileceği, yeni gelişmelerden haberdar olabileceği söylenebilir. Bu kriterle ilgili örnek görüşler: "Öğretmenin katıldığı hizmet içi eğitimler ve seminerler kriter olmalı." (S19), "Hizmet içi eğitimler, öğretmenin diğer başarılarn kariyer basamaklarmın oluşturulmasında değerlendirmeye katılmalı ancak belirli sinırlandırmalar yapılmalıdır." (M5)

10. Projeler ( $f=11$ ): Öğretmenin hazırladığı projeler kariyer basamaklarında bir kriter olarak kullanılmalı şeklinde değerlendirilmiştir. Bu kriterle ilgili örnek görüşler şu şekildedir: “...̈̈̆rretmenin ulusal ve uluslararası projelere katılması.” (S20, B17, Y10, M19), “...Geliştirdiği projeler kriter olabilir." (B17)

11. Yabancı $\operatorname{dil}(f=9)$ : Öğretmenin yabancı dil bilmesi kariyer basamaklarında yükselmede bir kriter olarak önerilmiştir. Bu kriterle ilgili örnek görüşler şu şekildedir: “...Başöğretmenlik için katıldığı seminerler, yabancı dil bilmesi, kendini geliştirdiği konulara bakılabilir." (Y17), “... Başöğretmenlikte yabancı dil bilmesi kriter olarak kullanılmalıdır." (Y17, Y20)

12. Eleyici olmayan mülakat $(f=5)$ : Katılımcılar mülakat sınavı ile ilgili olumlu düşüncelere sahip olmadıkları söylenebilir. Katılımcıların 11'i mülakat olmaması gerektiğini söylerken, 5’i mülakatın olması gerektiğini ancak eleyici olmaması gerektiğini vurgulamaktadırlar. Türkiye' de yapılan mülakat sınavlarına karşı tepkinin de göstergesi olarak ileri sürülebilir. Bu kriterle ilgili örnek görüssler şu şekildedir: "...Mülakat olmalı (objektif olarak yapılacaksa) ancak eleyici olmamalıdır." (Y9, M18), “...Mülakat puanı kullanılsa bile, sınav puanı ve yüksek lisans puanının getirdiği etkiden çok az etkisi olmalıdır. Ortalamaya etkisi az olacak şekilde planlanmalıdır. Sadece mülakata bağhı bir değerlendirme subjektif bir uygulamadır. Doğru bulmuyorum." (M14)

13. Milli ve manevi değerler (f=4): Katılımclardan 4 'ü öğretmenin milli ve manevi değerlere bağlılığının bir kriter olması gerektiğini önermişlerdir. Bu kriterle ilgili örnek görüşler şu 
şekildedir: “..Öğretmenin devleti koruyup kollaması." (Y2, M7), “... Milli ve manevi değerlere bağhllı̆̆ı." (Y5, B18)

14. Üst kurul tarafindan değerlendirme $(f=4)$ : Öğretmen kariyer basamaklarının oluşturulmasında belirlenen kriterleri değerlendiren bir kurulun olması gerektiği, değerlendirmeyi bu kurulun yapması gerektiğini belirtmektedir. Bu kriterle ilgili örnek görüşşu şekildedir: “...Kriterler bir kurul tarafindan değerlendirilmeli birden çok kriter değerlendirmeye katılmalıdır." (B6, B9, B10, B11)

15. Etik kurallar $(f=2)$ : Öğretmen kariyer basamaklarında yükselmede etik kurallara bağlllıkta kriter olarak önerilmiştir. Bu kriterle ilgili örnek görüşler şu şekildedir: “...Mesleki etik kurallarna uygun davranması." (Y5, B18), “...Mesleki etik kurullarna uyuyor mu, bu kriterler oluşturmalıdır." (Y5)

Öğretmen Kariyer Basamakları ilişkin oluşturulmasında kabul görmeyen, istenilmeyen kriterler $(f=35)$ : İstenilmeyen kriterler; mülakat olmamalı $(\mathrm{f}=11)$, merkezi sinav olmamalı $(\mathrm{f}=7)$, ödül ve cezalar objektif verilmiyor, bu nedenle kriter olmamalı $(f=4)$, kıdem ölçü değil bu nedenle kriter olmamalı (f=3) şeklinde dört kategoride toplanmıştır.

1. Mülakat olmamalı $(f=11):$ Katılımcıların öğretmen kariyer basamaklarının oluşturulmasında mülakat sınavının olmasını istemedikleri anlaşılmaktadır. Mülakatın sübjektif bir değerlendirme biçimi olacağı vurgulanmıştır. Bu kriterle ilgili örnek görüş şu şekildedir: "Mülakat sübjektif bir değerlendirmedir bu nedenle kullanılmamalıdır." (S16, Y10)

2. Merkezi sinav olmamalı $(f=7)$ : Katılımcılardan 7'si, kariyer basamaklarının oluşturulmasında merkezi sınavın olmasına karşı çıkmaktadırlar. Bu kriterle ilgili örnek görüşler şu şekildedir: "... Sadece sinava dayıl bir sistem olmamalıdır." (S4, Y9, M6), “.. Uzman öğretmenlikte stnav olursa genç öğretmenler iyi öğretmen olmadiğı halde başarılı olabiliyor." (Y19)

3. Ödül ve cezalar objektif verilmiyor $(f=4)$ : Katılımcilar ödül ve cezaların objektif yollarla elde edilmediğini bu nedenle kriter olarak kullanılmamasını ileri sürmektedirler. Bu kriterle ilgili örnek görüşler şu şekildedir: "Akademik kriterler, aldı̆̆ı ödüller olabilir. Ancak ödüller adamı olana veriliyor. Her yıl teklif ettiğgimiz öğretmene ödül verilmiyor. Mesela ödül objektif olarak verilecekse kullanılabilir." (Y13), "Öğretmenlerin almış olduğu ödüllerin, başarı belgelerinin objektif olarak verildiğini düşünmediğim için bu belgenin kriter olarak değerlendirmesini uygun bulmuyorum." (M14)

4. Kıdem ölçü değil(f=3): Öğretmenin kıdeminin bir kriter olmaması gerektiğini öneren katılımcılar, kıdem ile öğretmenin başarısının aynı şey olmadığını, öğretmenin emeğinin görülmediğini belirtmişlerdir. Bu kriterle ilgili örnek görüşler şu şekildedir: “... Kıdem ölçü değildir." ( S17, S20), “...kıdem ölçü değildir, kriter olmamah." (M13) 
Öğretmen Kariyer Basamakları ilişkin oluşturulmasında istenilmeyen kriterler (f=35): mülakat olmamalı ( $\mathrm{f}=11)$, merkezi sınav olmamalı ( $\mathrm{f}=7)$, ödül ve cezalar olmamalı, kıdem olmamalı olarak sıralanmıştır. İstenilen kiriterlerde belirtilen eleyici olmayan mülakat estenirken, istenmeyen kriterlerde mülakat olmaması istenmiştir. Bu görüşler, mülakata olan güvensizliği yansıtmaktadır. İstenilmeyen kriterler Milli Eğitim Bakanlığının ölçme ve değerlendirme kirterlerine olan güvensizliğin göstergesi olabilir. Katılımcılar, mülakat sınavlarına ve verilen ödül ve cezalara güvenmemekte bunların subjektif olarak verildiğini, merkezi sınava güvenmemekte bu sınavlarda gençlerin başarılı olacağını düşünmektedirler. Bu tür algılar katılımcıların daha önceki olumsuz algılarından kaynaklandığı söylenebilir. Bu olumsuz algılar objektif değerlendirme kriterleri oluşturularak ve nesnel olarak uygulanarak süreç içinde giderilebilir.

Katılımcıların çoğunluğunun görüşleri doğrultusunda öğretmen kariyer basamaklarının oluşturulmasında kullanılması önerilen kriterler; denetim ve değerlendirme sonuçları, merkezi sınav, yüksek lisans ve doktora yapma, öğretmenin aldığı ödül ve cezalar, öğretmenin teknik, sosyal, kültürel ve sportif becerileri, öğretmenin yayınları (kitap, makale), kıdem ve çalıştığı yer, öğretmenin hazırladığı yurt içi ve yurt dışı projeler, hizmet içi eğitime katılma, yabancı dil bilmesi, eleyici olmayan mülakat, milli ve manevi değerler, etik kurallar olarak sıralanmıştır. Bunun karşısında, mülakat olmaması, merkezi sınavın kriter olarak kullanılmaması gerektiği, ödül ve cezanın objektif verilmemesinden dolayı kullanılmaması gerektiği, kıdemin bir ölçü olmaması gerektiği vurgulanmıştır.

Tablo 4.

Katılımciların, "Kariyer basamaklarında yükselmede, öğretmen değerlendirme verileri, hizmet içi eğitim programlarına katılma, alanında veya eğitim bilimleri alanında yüksek lisans, doktora yapma, yayın yapma (makale, kitap vs) gibi kriterler ile yarışma sınavlarmdan alınan puanlar esas alınır." Sorusuna Verdikleri Cevaplarm Frekans, Yüzde ve Ki Kare Sonuçları

\begin{tabular}{|c|c|c|c|c|c|c|c|c|}
\hline & \multirow{2}{*}{\multicolumn{2}{|c|}{$\begin{array}{c}\text { Hiç } \\
\text { Katılmiyorum }\end{array}$}} & \multirow{2}{*}{$\begin{array}{c}\mathrm{Az} \\
\text { Katılıyorum }\end{array}$} & \multirow{2}{*}{$\begin{array}{c}\text { Orta Düzeyde } \\
\text { Katıliyorum }\end{array}$} & \multirow{3}{*}{$\begin{array}{c}\begin{array}{c}\text { Büyük Ölçüde } \\
\text { Katılıyorum }\end{array} \\
24\end{array}$} & \multirow{2}{*}{$\begin{array}{c}\text { Tamamen } \\
\text { Katıliyorum }\end{array}$} & \multirow{2}{*}{ Toplam } \\
\hline & & & & & & & & \\
\hline \multirow{6}{*}{ 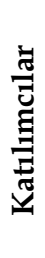 } & \multirow{2}{*}{ Müfettiş } & $\mathrm{f}$ & 4 & 3 & 3 & & 31 & 65 \\
\hline & & $\%$ & $6,2 \%$ & $4,6 \%$ & $4,6 \%$ & $36,9 \%$ & $47,7 \%$ & $100,0 \%$ \\
\hline & \multirow{2}{*}{$\begin{array}{l}\text { Okul } \\
\text { Yöneticisi }\end{array}$} & $\mathrm{f}$ & 2 & 2 & 3 & 15 & 25 & 47 \\
\hline & & $\%$ & $4,3 \%$ & $4,3 \%$ & $6,4 \%$ & $31,9 \%$ & $53,2 \%$ & $100,0 \%$ \\
\hline & \multirow{2}{*}{ Öğretmen } & $\mathrm{f}$ & 44 & 33 & 60 & 80 & 43 & 260 \\
\hline & & $\%$ & $16,9 \%$ & $12,7 \%$ & $23,1 \%$ & $30,8 \%$ & $16,5 \%$ & $100,0 \%$ \\
\hline \multirow{2}{*}{\multicolumn{2}{|c|}{ Toplam }} & $f$ & 50 & 38 & 66 & 119 & 99 & 372 \\
\hline & & $\%$ & $13,4 \%$ & $10,2 \%$ & $17,7 \%$ & $32,0 \%$ & $26,6 \%$ & $100,0 \%$ \\
\hline \multirow{2}{*}{\multicolumn{4}{|c|}{ Pearson Ki-Kare }} & Değer & sd & & $\mathbf{p}$ & \\
\hline & & & & $60,817 \mathrm{a}$ & 8 & & 000 & \\
\hline
\end{tabular}

ÖSMG anketinin "Kariyer basamaklarında yükselmede, öğretmen değerlendirme verileri, hizmet içi eğitim programlarına katılma, alanında veya eğitim bilimleri alanında yüksek lisans, doktora yapma, yayın yapma (makale, kitap vs) gibi kriterler ile yarışma sınavlarından alınan puanlar esas alınır." 
sorusuna müfettiş ve okul yöneticilerinin cevaplarının birbirlerine benzer oldukları, ancak öğretmenlerin cevaplarının farklılaştığı anlaşılmaktadır. Bu ifadenin "hiç katılmama" ve "az katılma" seçeneklerine müfettişler ve okul yöneticileri \% 7-\% 4 arasında katılırken öğretmenlerin \% 77 'si bu seçeneklerde görüş bildirmişlerdir. Yapılan ki-kare analizinde de bu üç gruba göre bu ifadeye katılma dereceleri arasında fark olduğu anlaşılmaktadır. Hesaplanan ki-kare değeri $(60,817)$ 0,05 manidarlık düzeyinde anlamlı bulunmuştur. Katılımclların verdiği cevapların toplamına bakıldığında; hiç katılmıyorum $50(\% 13,4)$, az katıllyorum $38(\% 10,2)$, orta düzeyde katılıyorum 66 (\%17,7), büyük ölçüde katıllyorum 119 (\% 32), tamamen katılıyorum 99 $(\% 26,6)^{\prime}$ dur. Bu soruya; araştırmaya katılan 372 kişinin 322'u (\% 86,6) tarafından kabul görmüştür. Araştırmanın nitel bulguları, nicel bulguları ile doğrulanmıştır ve tutarlılık göstermekter. Araştırmada öğretmen kariyer basamaklarının belirli kriterler doğrultusunda oluşturulması düşüncesi benimsenmiş olduğu ortaya çıkmıştır.

Araştırmanın nitel ve nicel katılımcllarının görüşlerine göre; Öğretmen kariyer basamaklarının oluşturulmasında kullanilabilecek kriterler; "öğretmenin; denetim ve değerlendirme sonuçları, merkezi sınav sonuçları, yüksek lisans ve doktora yapması, aldığı ödül ve cezaları, teknik, sosyal, kültürel ve sportif becerileri, yayınları (kitap, makale), kıdem ve çalıştığı yer, hazırladığı projeleri, katıldı̆̆ı hizmet içi eğitim kurslarl, yabancı dil bilmesi" şeklinde sıralanabilir. Bu kriterler kariyer basamaklarında yükselmede en çok atıf alan kriterlerdir.

\section{c. Kariyer Basamaklarının Sıralaması İle İlgili Bulgular}

Nitel verilere göre; katılımcıların kariyer basamakları nasıl sıralanmalıdır sorusuna verdikleri cevaplar Tablo 5'te özetlenmiştir.

Tablo 5.

Katılımcıların, Kariyer Basamaklarının Sıralamasına İlişkin Görüşleri

\begin{tabular}{llc}
\hline \multicolumn{1}{c}{ Tema } & \multicolumn{1}{c}{ Kategori } & f \\
\hline & Aday Öğretmen, Öğretmen, Uzman Öğretmen, Başögretmen & 51 \\
& Aday Öğretmen, Öğretmen, Uzman Öğretmen & 5 \\
\multirow{2}{*}{ Kariyer basamağ1 } & Aday öğretmen, Öğretmen, Uzman Öğretmen, Müdür & 1 \\
önerileri & Aday öğretmen, Öğretmen, Uzman Öğretmen, Başöğretmen, Okul & 1 \\
& Müdürü & 1 \\
& Birinci, ikinci ve üçüncü basamak & 1 \\
\hline 1. Kademe, 2. Kademe, 3. Kademe & 60 \\
\cline { 2 - 3 }
\end{tabular}

Tablo 5'te katılımcıların kariyer basamakları sıralaması nasıl olmalıdır soruna verdikleri cevaplar incelendiğinde: kariyer basamağı önerileri temasında ( $\mathrm{f}=60)$; aday öğretmen, öğretmen, uzman öğretmen, başöğretmen ( $f=51$ ), Aday öğretmen, öğretmen, uzman öğretmen(f=5), aday öğretmen, öğretmen, uzman öğretmen, okul müdürü (f=1), Aday öğretmen, öğretmen, uzman öğretmen, başöğretmen, okul müdürü (f=1), birinci, ikinci, üçüncü basamak(f=1), birinci kademe 
öğretmen, ikinci kademe öğretmen, 3. kademe öğretmen ( $\mathrm{f}=1$ ) olmak üzere altı kategoride değerlendirilmiştir. Katılımcıların çoğunluğu ( $\mathrm{f}=51)$, kariyer basamaklarını, "aday öğretmen, öğretmen, uzman öğretmen ve başöğretmen" olarak belirtmişlerdir.

Nicel verilere göre; Katılımcıların Tablo 3'de, “Aday öğretmen, öğretmen, uzman öğretmen, başöğretmen biçiminde kariyer basamakları ve özlük hakları oluşturulur." Maddesine verilen cevapların toplamına bakıldığında; hiç katılmıyorum 83 (\%22,3), az katılıyorum 29 (\%7,8), orta düzeyde katılıyorum 63 (\%16,9), büyük ölçüde katılıyorum 86 (\% 23,1), tamamen katılıyorum 111 $(\% 29,8)^{\prime}$ dur. Bu soruya; araştırmaya katılan 372 kişinin 289'u $(\% 77,7)$ tarafından kabul görmüştür. Bu veriler nitel veriler ile tutarlılık göstermektedir. Katılımcıların şuan yürürlükte olan yasalarda belirtilen kariyer basamağı sınıflandırmasını doğru bulduğu, kariyer basamağında yükselmede yarışma sınavı ve kıdemin yeterli olmadığı görüşünde birleştikleri ortaya çıkmıştır.

Araştırmanın nitel verileri ve nicel verilerinde elde edilen bulgulara göre; kariyer basamakları, "aday öğretmen, öğretmen, uzman öğretmen ve başöğretmen" olarak sıralanmıştır.

\section{d. Kariyer Basamaklarında Üst Kariyerdeki Öğretmenlerden Yararlanma İle İlgili}

\section{Bulgular}

Nitel verilere göre; Öğretmen kariyer basamaklarında üst kariyer basamağındaki öğretmenlerden nasıl yararlanılacağı Tablo 6’ da sunulmuştur.

Tablo 6.

Katılımcıların, Üst Kariyer Basamă̆a Geçmiş Uzman ve Başöğretmenlerden Nasıl Yararlanılabileceğine İlişkin Görüşleri

\begin{tabular}{llc}
\hline Tema & Kategori & f \\
\hline & Öğretmen geliştirmede görev verilmesi & 25 \\
& Öğretmenlere seminer, panel, toplantılarda görevlendirilmesi & 20 \\
& Öğretmene rehberlik yapması & 12 \\
Rehberlik ve öğretmen & Örnek uygulamaların paylaşılması & 10 \\
geliştirme & Mentörlük yapması & 8 \\
& Aday öğretmen yetiştirmede görev verilmesi & 7 \\
& Başarısız öğretmenlerin geliştirilmesi & 5 \\
& Veli ve öğrencilere seminer verilmesi & 2 \\
& Toplam & 90 \\
\hline \multirow{4}{*}{ Değerlendirme } & Öğretmen değerlendirmede görev verme & 16 \\
& Haftada bir gün başka okulda öğretmen değerlendirme & 3 \\
& Ö̆̆retmen değerlendirmede görev vermeme & 2 \\
\cline { 2 - 3 } & Toplam & 21 \\
\hline \multirow{3}{*}{$\begin{array}{l}\text { Kariyer basamaklarında } \\
\text { yükselmede öncelik verilme }\end{array}$} & Okul müdürlüğüne geçişte öncelik verilme & 6 \\
& Müfettiş, şube müdürlüğüne geçişte öncelik verilme & 6 \\
\cline { 2 - 3 } & Toplam ve diğer toplantılarına başkan olma & 2 \\
\hline
\end{tabular}

Tablo 6 katılımcıların, üst kariyer basamağa geçmiş uzman ve başöğretmenlerden nasıl yararlanılabileceğ̊ine ilişkin görüşler; “Rehberlik ve öğretmen geliştirme" teması (f= 90), 
“Değerlendirme" teması ( $\mathrm{f}=21)$, "Kariyer basamaklarında yükselmede öncelik verilme" teması $(\mathrm{f}=14)$ olmak üzere üç tema altında değerlendirilmiştir.

"Rehberlik ve öğretmen geliştirme" teması ( $\mathrm{f}=90$ ) altında; "öğretmen geliştirmede görev verilmesi" ( $f=25)$, “öğretmenlere seminer, panel, toplantılarda görevlendirilmesi” ( $f=20)$, “öğretmene rehberlik yapması" ( $\mathrm{f}=12)$, “örnek uygulamaların paylaşılması” ( $\mathrm{f}=10)$, “Mentörlük yapması" ( $\mathrm{f}=8$ ), "Aday öğretmen yetiştirmede görev verilmesi" ( $\mathrm{f}=7$ ), "başarısız öğretmenlerin geliştirilmesi" ( $\mathrm{f}=5)$, "veli ve öğrencilere seminer verilmesi" $(\mathrm{f}=2)$ şeklinde kategoriler oluşturulmuştur. Bu kategorilere ait örnek görüşler şu şekildedir: “...Uzman ve başöğretmenler diğer öğretmenin geliştirilmesinde kullanılabilir." (S16, B14), “...Uzman ve başöğretmenlere okullarda örnek uygulamalar yaptırlabilir." (B17, Y20, M21), “...Uzman ve başöğretmenlerin çalışmalar video çekimleri yolu ile diğer öğretmenlerle paylaşılabilir." (S13, B17, M21), “...Ders denetiminde başarısız olan öğretmenlerin geliştirilmesinde görevlendirilebilir." (B20), “...Uzman ve başöğretmenler diğer öğretmenlere rehberlik amaçl görevlendirilebilir." (S13). Rehberlik ve öğretmen geliştirme teması altında; uzman ve başöğretmenlere öğretme geliştirmede görev verilmesi, öğretmenlere seminer, panel, toplantılarda görev verilmesi, öğretmene rehberlik yapması, örnek uygulamaların paylaşımı, mentörlük yapması, aday öğretmen yetiştirmede görev verilmesi, başarısız öğretmenlerin geliştirilmesi görüşleri ön plana çıkmaktadır.

"Değerlendirme" teması ( $\mathrm{f}=21$ ) altında; "öğretmen değerlendirme görev verme" ( $\mathrm{f}=16)$, "haftada bir gün başka okulda değerlendirme" ( $f=3)$, "öğretmen değerlendirme görev vermeme" $(\mathrm{f}=2)$, şeklinde üç kategori oluşturulmuştur. Bu tema altındaki örnek görüşler şu şekildedir: “...Uzman ve başöğretmenlere öğretmen değerlendirilmesinde görev verilebilir." (B19, Y9), "...Uzman ve başöğretmenler çalıştı̆̆ı beş günün bir gününü başka okullarda öğretmen değerlendirmesi yaparak, diğer günlerini okulunda geçirebilir.” (S19, B17, M15), “...Uzman ve başöğretmenin ders denetiminde görev almasını uygun bulmuyorum. Ders denetimi uzmanlık işidir." (M12, M19). Değerlendirme teması altında; öğretmen değerlendirme görev verme, haftada bir gün başka okulda değerlendirmede görev verme görüşleri ön plana çıkmıştır.

"Kariyer basamaklarında yükselmede öncelik verilme" teması ( $\mathrm{f}=14)$ altında; "okul müdürlüğüne geçişte öncelik verilme" (f=6), "müfettiş, şube müdürlüğüne geçişte öncelik verilme" (f=6), "zümre ve diğer toplantılarına başkan olma" (f=2) şeklinde üç kategoride toplanmıştır. Bu tema altındaki örnek görüşler şu şekildedir: “...Okul müdürlüğü seçiminde uzman ve başöğretmenlere öncelik verilmelidir." (Y5), “...Okul müdürü, müfettiş, şube müdürleri vs başöğretmenler arasından seçilmesi öğretmenin mesleki gelişimine olumlu katkısı olabilir." (S17, Y19, M14), “...Uzman ve başöğretmenler zümre öğretmenler toplantılarında başkan olabilir, diğer toplantılarda başkanlık yaptırılabilir." (Y19). Katılımcıların, üst kariyer basamağa geçmiş uzman ve başöğretmenlerden nasıl yararlanılabileceğine ilişkin görüşler; "Rehberlik ve öğretmen 
geliştirme" teması ( $(\mathrm{f}=90)$, “Değerlendirme" teması $(\mathrm{f}=21)$, "Kariyer basamaklarında yükselmede öncelik verilme" teması ( $\mathrm{f}=14)$ şeklinde temalar belirlenmiştir. Üst kariyer basamağındaki öğretmenlerden; öğretmen geliştirilmesi, öğretmenlerin değerlendirilmesinde yararlanılabilir. Bu öğretmenler kariyer basamaklarında yükselmede öncelikli hale getirilebilir.

Nicel verilere göre; öğretmen kariyer basamağından üst basamakta bulunan öğretmenlerden nasıl yararlanılabileceği ilgili görüşler Tablo 7'de özetlenmiştir.

Tablo 7.

Katılımciların, "Kariyer basamaklarında üst basamakta bulunan "uzman öğretmen ve başöğretmenler" meslektaş değerlendirmelerinde ve denetim sonucunda "yetersiz" ve "geliştirilmeye açı" sonuçlar alan ögretmenlerin geliştirilmesinde görev verilir." Sorusuna Verdikleri Cevapların Frekans, Yüzde ve Ki Kare Sonuçları

\begin{tabular}{|c|c|c|c|c|c|c|c|c|}
\hline & & & $\begin{array}{c}\text { Hiç } \\
\text { Katılmıyorum }\end{array}$ & $\begin{array}{c}\mathrm{Az} \\
\text { Kat1liyorum }\end{array}$ & $\begin{array}{l}\text { Orta Düzeyde } \\
\text { Katıliyorum }\end{array}$ & $\begin{array}{c}\text { Büyüuk Ölçüde } \\
\text { Katılıyorum }\end{array}$ & $\begin{array}{c}\text { Tamamen } \\
\text { Katıliyorum }\end{array}$ & Toplam \\
\hline \multirow{6}{*}{ 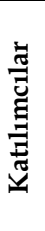 } & \multirow{2}{*}{ Müfettiş } & $\mathrm{f}$ & 7 & 6 & 14 & 20 & 18 & 65 \\
\hline & & $\%$ & $10,8 \%$ & $9,2 \%$ & $21,5 \%$ & $30,8 \%$ & $27,7 \%$ & $100,0 \%$ \\
\hline & \multirow{2}{*}{$\begin{array}{l}\text { Okul } \\
\text { Yöneticisi }\end{array}$} & $\mathrm{f}$ & 3 & 1 & 8 & 15 & 20 & 47 \\
\hline & & $\%$ & $6,4 \%$ & $2,1 \%$ & $17,0 \%$ & $31,9 \%$ & $42,6 \%$ & $100,0 \%$ \\
\hline & & $\mathrm{f}$ & 69 & 29 & 66 & 67 & 29 & 260 \\
\hline & Öğretmen & $\%$ & $26,5 \%$ & $11,2 \%$ & $25,4 \%$ & $25,8 \%$ & $11,2 \%$ & $100,0 \%$ \\
\hline \multirow{2}{*}{\multicolumn{2}{|c|}{ Toplam }} & $\mathrm{f}$ & 79 & 36 & 88 & 102 & 67 & 372 \\
\hline & & $\%$ & $21,2 \%$ & $9,7 \%$ & $23,7 \%$ & $27,4 \%$ & $18,0 \%$ & $100,0 \%$ \\
\hline \multicolumn{4}{|c|}{ Pearson Ki-kare } & $\begin{array}{c}\text { Değer } \\
43,130^{a}\end{array}$ & $\begin{array}{c}\text { sd } \\
8\end{array}$ & & $\begin{array}{c}\mathbf{p} \\
000\end{array}$ & \\
\hline
\end{tabular}

ÖSMG anketinin "Kariyer basamaklarında üst basamakta bulunan "uzman öğretmen ve başöğretmenler" meslektaş değerlendirmelerinde ve denetim sonucunda "yetersiz" ve "geliştirilmeye açı" sonuçlar alan öğretmenlerin geliştirilmesinde görev verilir." sorusuna müfettiş ve okul yöneticilerinin cevaplarının birbirlerine benzer oldukları, ancak öğretmenlerin cevaplarının farklılaştığı anlaşılmaktadır. Bu ifadenin "hiç katılmama" ve "az katılma" seçeneklerine müfettişler ve okul yöneticileri \% 13-\% 4 arasında katılırken öğretmenlerin \% 69'u bu seçeneklerde görüş bildirmişlerdir. Yapılan ki-kare analizinde de bu üç gruba göre bu ifadeye katılma dereceleri arasında fark olduğu anlaşılmaktadır. Hesaplanan ki-kare değeri $(43,130)$ 0,05 manidarlık düzeyinde anlamlı bulunmuştur. Katılımcıların verdiği cevapların toplamına bakıldı̆̆ında; hiç katılmıyorum 79 (\%21,2), az katılıyorum $36(\% 9,7)$, orta düzeyde katılıyorum 88 (\%23,7), büyük ölçüde katılıyorum 102 (\% 27,4), tamamen katılıyorum 67 (\%18)'dur. Bu soruya; araştırmaya katılan 372 kişinin 293’ü $(\% 78,8)$ tarafından kabul görmüştür.

"Kariyer basamaklarında üst basamakta bulunan "uzman öğretmen ve başöğretmenler" meslektaş değerlendirmelerinde ve denetim sonucunda "yetersiz" ve "geliştirilmeye açık" sonuçlar alan öğretmenlerin geliştirilmesinde görev verilir." $X=3,19=$ Orta düzeyde uygulanabilir bulmaktadırlar. Katılımcılar, öğretmenin sürekli mesleki gelişiminde öğretmenin içsel motivasyonunu harekete geçirmek için kariyer basamaklarının oluşturulmasını orta düzeyde uygulanabilir bulmuşlardır. Araştırmanın nitel verilerinde ( $\mathrm{f}=70 ; \%$ 87) kariyer basamaklarının 
oluşturulması yüksek düzeyde kabul görürken, nicel verilerinde ( $f=289 ; \% 77,7)$ orta düzeyde kabul görmüştür. Araştırmanın nitel verileri ile nicel verileri orta düzeyde de olsa tutarlılık göstermiştir.

Kariyer basamaklarında üst basamaktaki uzman ve başöğretmenlerden; öğretmen geliştirme ve rehberliğinde, başarısız öğretmenlerin geliştirilmesi, veli ve öğrencilere seminer verilmesi, öğretmen değerlendirmede, başka okullarda öğretmen değerlendirmede, okul müdürlüğüne, müfettişliğe ve şube müdürlüğ̈̈ne geçişte öncelik verilmesi gibi alanlarda yararlanılabileceği yönünde bulgularına ulaşılmıştır.

\section{TARTIŞMA VE SONUÇ}

Öğretmen kariyer basamakları oluşturulması öğretmenin mesleki gelişimine katkısı olacağı sonucuna ulaşılmıştır. Nitel verilerinde kariyer basamaklarının oluşturulması yüksek düzeyde kabul görürken, nicel verilerinde orta düzeyde kabul görmüştür. Araştırmanın nitel verileri ile nicel verileri orta düzeyde de olsa tutarlılık göstermiştir. Öğretmen kariyer basamaklarının oluşturulması öğretmenin içsel motivasyonuna katkı yapabileceği bulgularına ulaşılmıştır. Öğretmen kariyer basamaklarında yükselmek için göstereceği çaba ile mesleki anlamda gelişimine önemli katkılar sunabileceği değerlendirilmiştir. Kariyer basamaklarının yeniden tasarlanarak, yasal alt yapısının oluşturulması öğretmenin mesleki gelişimine katkı sunabilir, şeklinde sonuçlara ulaşılmıştır.

Öğretmen kariyer basamaklarının oluşturulması: Öğretmeni geliştirme aracı olabileceği, öğretmenin gelişimini tetikleyen süreç olduğu, maddi getirisi olması durumunda daha etkili olabileceği, öğretmen performansını nesnel olarak ölçülmesine yardımcı olabileceği, "çalışana ödül" olduğu şeklinde olumlu görüşler öne çıkarken; kariyer basamaklarının öğretmenin mesleki gelişimine etkisi olmayacağı, iş barışını bozacağı, öğretmenlik mesleğini gönül işi olduğu şeklinde karşı görüşler sırlanmıştır.

Öğretmen kariyer basamaklarında yükselmede; “öğretmenin denetim ve değerlendirme sonuçları, merkezi sınav sonuçları, yüksek lisans ve doktora yapması, aldı̆̆ı ödül ve cezaları, teknik, sosyal, kültürel ve sportif becerileri, yayınları (kitap, makale), kıdem ve çalıştığı yer, hazırladığı projeleri, katıldığı hizmet içi eğitim kursları, yabancı dil bilmesi" şeklinde kriterler kullanılması sonuçlarına ulaşılmıştır.

Araştırmanın nitel verileri ve nicel verilerinde elde edilen sonuçlara göre; kariyer basamakları, "aday öğretmen, öğretmen, uzman öğretmen ve başöğretmen” olarak sıralanmıştır. Crehan, (2016, s. 82) göre performansa dayılı kariyer basamaklarını (novice teacher, career teacher, and master teacher) acemi öğretmen, öğretmen, uzman öğretmen olarak tanımlanmıştır. Crehan'ın bulguları ile araştırma bulguları benzerlik göstermektedir. 
Kariyer basamaklarında üst basamaktaki uzman ve başöğretmenlerden; “öğretmen geliştirme ve rehberliğinde, başarısız öğretmenlerin geliştirilmesi, veli ve öğrencilere seminer verilmesi, öğretmen değerlendirmede, başka okullarda öğretmen değerlendirmede ve okul müdürlüğüne, müfettişliğe ile şube müdürlüğüne geçişte öncelik verilmesi" gibi çalışmalarda görev alması sağlanabilir.

Alanyazında; Kariyer basamaklarının oluşturulmasına yönelik yaşanan sorunlar; Türkiye'de 1739 Sayılı Milli Eğitim Temel Kanunun 43. maddesi ve 657 Sayılı Devlet Memurları Kanunun 152. Maddesi uyarınca; 13.08.2005 tarihinde Öğretmen Kariyer Basamaklarında Yükselme Yönetmeliği Yayınlanmıştır. Bu yönetmelikte; uzman öğretmenliğe ve başöğretmenliğe geçiş şartları belirlenmiştir. Yönetmeliğin 7. maddesinde toplam öğretmenlerin \% 20 kadar uzman öğretmen, \% 10 kadar başöğretmen kadrosu belirlenmiştir. Yukarıda adı geçen yasal metinler doğrultusunda; 2006 yılında uzman öğretmenlik sınavı yapılmış, MEB'na bağlı 558,305 öğretmenden 106,536'sı uzman öğretmenlik kariyerini elde etmiştir. Bu yönetmelik hükümlerine göre oluşturulan kariyer basamaklarında kıdem ve yarışma sınavı esası ağırlık kazanması nedeniyle sendikaların itirazlarına neden olmuş ve Öğretmen Kariyer Basamaklarında Yükselme Yönetmeliğinin iptali için Mahkemeye başvurmuşlardır. Anayasa Mahkemesinin 21.05.2008 tarihli E:2004/83 K:2008/107 sayılı kararı bu yönetmeliğin bazı maddelerini iptal etmiştir. Bu iptal kararından sonra uzman öğretmenlik ve başöğretmenlik sınavı yapılmamıştır. Anayasa Mahkemesinin kararından sonra öğretmen kariyer basamakları uygulanamamıştır. Kariyer basamaklarının yeni bir anlayışla yeniden düzenlenmesi ihtiyacı ortaya çıkmıştır.

2005 yılında uygulamaya konulan öğretmen kariyer basamakları uygulaması sonucunda yapılan araştırmalarda; uygulamanın yararlı olmadığı yünündeki araştırmalar (Bakioğlu ve Can, 2009; Gümüşeli, 2005; Kurt, 2007; Laçin, 2007; Utkutuğ 2007) ve yararlı sonuçlar doğurabileceği yönünde sonuçlara ulaşan araştırmalar (Can, 2019; Canbolat, 2011; Çakıroğlu, 2005; Taşkaya, 2007; Turun \& Turan, 2009; Deniz, 2009; Demir, 2011, Yang Keo, 2016; Özdemir \& Orhan 2019) bulunmaktadır. Öğretmen kariyer basamaklarının yararlı olabileceği yönündeki sonuçlarla araştırmamız tutarlılık göstermektedir.

Bakioğlu ve Banoglu (2013) tarafından yapılan araştırmada; Uzman öğretmenlerin kariyerlerini işlevsiz gördüklerini, kariyer basamaklarına uygulamasına ilişkin bulgular sınav sistemine yönelik eleştirilerin uygulamaya yönelik de olumsuz bir tutum oluşmasına neden olduğunu, eleştirilerin uygulamanın plansızlığı ve istikrarsızlığı üzerinde yoğunlaştı̆̆ı, sonuçlarına ulaşılmıştır. Dağlı'nın (2007) araştırma sonuçlarında uygulamaya yönelik temel eleştirilerin sınavın uygulama sıklığı ve sınav dışı performans değerlendirme ölçütlerine yoğunlaştığı, katılımcıların kariyer basamaklarının oluşturulmasını orta düzeyde uygulanabilir buldukları" belirtilmiştir. Öğretmenlik Kariyer Basamaklarında Yükselme Yönetmeliği, 
başöğretmen, uzman öğretmen ve öğretmenler tarafından genel olarak olumlu karşllansa da, uygulamanın süreklilik arzetmemesi nedeniyle öğretmen kariyer basamağında bulunanlar aleyhine adaletsizliklere ve haksızlıklara neden olacağı belirtilmiştir (Aydın, 2007; Demir, 2011). Laçin (2006) araştırmasında, kariyer basamaklarına ait başarı değerlendirme kriterlerinin güvenilir olmadığı sonucuna ulaşmıştır. Nartgün ve Ural'ın (2007) araştırma sonuçlarına göre; öğretmenlerin önemli bir kısmı, öğretmenlik mesleği kariyer basamaklarında yükselme uygulamasının, öğretmenin saygınlık, tanınma ve başarılı olma bakımından sosyal statüsünü yükseltmesi, öğretme sürecindeki etkililiğini artırma, iş doyumunu artırması, mesleki gelişimine imkan sağlaması, aidiyet duygusunu gelişmesini desteklemesi, yetenek ve becerilerini kullanma fırsatı sağlaması gibi konularda olumsuz düşünceye sahip olduklarını, yine öğretmenlerin büyük bir kısmı uygulamanın düzenlenmesi sürecine ve olası sonuçlarına ilişkin olumsuz düşünceler ifade etmişlerdir. Demir (2011) araştırmasında; kariyer basamakları oluşturma uygulamasının, ast üst ilişkileri ve örgüt içi hiyerarşi ile ilgili sorunlar, öğretmenler arası olumsuz duygu ve tutumlar oluşması, öğretmenler arası bölünme ve gruplaşma gibi olumsuz sonuçlar doğurduğu veya doğurabileceği öngörülmüştür. Ural (2011; s.406) araştırmasında; “Katılımcıların büyük bir çoğunluğunun öğretmenlik mesleği kariyer basamaklarında yükselme uygulamasının süreç boyutuna ilişkin değerlendirmesi olumsuzdur. Ayrıca, katılımcıların büyük bir bölümü öğretmenlik mesleği kariyer basamaklarında yükselme uygulamasının sonuçlarına ilişkin öngörülen olumlu etkilerinin yeteri kadar yansımadığını" belirtmiştir.

Öğretmen kariyer basamakları uygulamasının olumsuz sonuçlarından daha çok olumlu sonuçlar doğurduğunu, uygulamada süreklilik sağlanabilirse yönetmeliğin eğitim sistemimiz içinde olumlu sonuçlar doğurabileceği sonuçları ile araştırmamız tutarlılık göstermektedir. Uygulamanın öğretmenlik mesleğini tek düzelikten kurtarabileceği, öğretmen mesleği kariyer mesleği haline getirilebileceği belirtilmiştir (Demir, 2011). "Kariyer basamakları uygulamasının öğretmen boyutu ile; içsel motivasyon, dişsal motivasyon, normatif bağl1lık, duygusal bağlllık ve devam bağlılığı arasında ise pozitif bir ilişki mevcuttur" (Canbolat, 2011, s. 87). Öğretmen kariyer basamaklarının olumsuz görüşlere rağmen uygulanması gerektiğini, kariyer basamakları konusunda düzenli bilgilendirmenin gerektiği vurgulanmıştır (Dağlı, 2007). Gülcan'ın (2003), Avrupa Birliğine adaylık sürecinde Türkiye eğitim sisteminin yapısal sorunları ve yapısal uyum modeli, isimli araştırmasında; “Öğretmenlik mesleği; aday öğretmen, öğretmen, uzman öğretmen ve başöğretmen gibi unvanlara ayrılmalıdır." şeklinde bulgulara ulaşılmıştır. Yang Keo (2016, s. 95); öğretmen kariyer basamaklarının oluşturulması “Öğretmenin bireyselliği için, kariyer basamağı, farklı roller ve sorumluluklar aracılığıyla kariyerlerinin sürekliliği boyunca sürekli mesleki ve liderlik gelişimini destekler ve ödüllendirir. Bu, yüksek performanslı bireyleri mesleğe çekmeye ve mükemmel öğretmenleri tutmaya yardımcı olacaktır. Öğretmen kariyer basamakları ayrıca okulları profesyonel çalışma organizasyonlarına dönüştürür ve daha güçlü, 
sürekli gelişen bir öğretmenlik mesleğini desteklemek için altyapı oluşturur. Toplamda ve zamanla, güçlü bir meslek, yüksek düzeyde öğrenci başarısının yanı sıra ülke çapında yüksek performanslı ve adil okul sistemlerini yönlendirecektir." Şeklinde sonuçlara ulaşmıştır. Ayrıca; Sağ'ın (2004), Tosun ve Sarpkaya (2014) ve Utkutuğ'un (2007) yaptıkları araştırmalarda öğretmen kariyer basamaklarının oluşturulmasına ilişkin öğretmen görüşleri arasında cinsiyete göre anlamlı bir farklılık ortaya çıkmıştır.

Yukarıdaki araştırmacılar farklı sonuçlara ulaşmış olsa da, dünyada “Uluslararası Öğrenci Değerlendirme Programı" yada PISA isimli sınav sıralamasında üst sırada bulunan bazı ülkelerde öğretmen kariyer basamakları uygulanmaktadır. Farklı şekil ve kademelerde, öğretmen kariyer basamakları uygulayan ülkeler; İngiltere, Sangay (Cin), Singapuru, Güney Kore, Çek Cumhuriyeti, Polonya, Portekiz, Slovakya, İspanya, İşviçre, İsveç, Yeni Zellanda, Avusturya, Amerika Birleşik Devletlerinde Arizona, İlinoy ve Mizuri eyaletleri, Estonya, Gana, vs. sayılabilir. Bu ülkelerdeki öğrenci başarılarını sadece öğretmen kariyer basamaklarına bağlı olduğunu söylemek olanaklı olmamasına rağmen, göstergelerden birisidir. Öğretmenin moral motivasyonunun yüksekliğinin öğrenci başarısında etkili olabileceğini söylemek mümkündür.

Bakioğlu ve Banoglu (2013) araştırma sonuçlarına ilişkin önerilerinde; “Öğretmen kariyer basamaklarına yönelik olumlu tutum geliştirilmesi için var olan uzman öğretmenlerin kariyer gelişimiyle ilgili teşvik edici çalışmalar yapılmalıdır. Kariyer Belirleme Sınavı en kısa sürede tekrar edilerek, uygulamanın planlı ve istikrarlı bir şekilde süreceğine dair öğretmenlere güvence verilmelidir. Kariyer basamaklarında yükselmek için sınav dışında uygulanabilecek performans değerlendirme yöntemleri bir an önce gündeme getirilmelidir..." önerisi ve Dağlı'nın (2007) kariyer basamaklarından oluşturulmasında; "(1) performansa dayalı ölçütler geliştirilmeli ve bu ölçütler objektif olmalıdır. (2) hizmet-içi eğitime ağırlık verilmelidir ve (3) öğretmenlere yüksek lisans yaptıklarında uzman öğretmen ve doktora yaptıklarında ise başöğretmen unvanı verilmelidir." şeklindeki sonuçları ile araştırmamızda elde edilen bulgular benzerlik göstermektedir. Araştırmada, kariyer basamaklarında yükselmede sınav sisteminin yanında başka performans ölçme kriterlerinden de yararlanılması görüşü ağırlık kazanmıştır.

\section{ÖNERILER}

1. Kariyer basamaklarının yeniden tasarlanarak, yasal alt yapısının oluşturulması öğretmenin mesleki gelişimine katkı sunabilir. MEB tarafından öğretmen kariyer basamakları uygulaması kararlı olarak uygulanmalı ve sürekliliği sağlanmalıdır.

2. Öğretmen kariyer basamaklarının oluşturulması; öğretmeni geliştirme aracı ve öğretmenin gelişimini tetikleyen süreç olabilir. Ayrıca, maddi getirisi olması durumunda daha etkili olabileceği görüşleri doğrultusunda, basamaklar arasında maaş veya ücret farkı oluşturulmalıdır. 
3. Öğretmen kariyer basamaklarında yükselmede; “öğretmenin; denetim ve değerlendirme sonuçları, merkezi sınav sonuçları, yüksek lisans ve doktora yapması, aldığı ödül ve cezaları, teknik, sosyal, kültürel ve sportif becerileri, yayınları (kitap, makale), kıdem ve çalıştığı yer, hazırladığı projeleri, katıldığı hizmet içi eğitim kursları, yabancı dil bilmesi” şeklinde kriterler kullanılabilir.

4. Öğretmen kariyer basamakları sıralamasının, 1739 sayılı Kanunun 43. Maddesinde belirtilen "aday öğretmen, öğretmen, uzman öğretmen ve başöğretmen" olarak kullanılmaya devam edilerek, bunun uygulamasına yönelik yönetmelik oluşturulmalıdır.

5. Kariyer basamaklarında üst basamaktaki uzman ve başöğretmenlerden; “öğretmen geliştirilmesinde, rehberliğinde, denetiminde, veli ve öğrencilere seminer verilmesinde, başka okullarda öğretmen değerlendirmede" yararlanılabilir. Ayrıca, okul müdürlüğüne, şube müdürlüğüne ve müfettişliğe geçişte, uzman ve baş öğretmenlere öncelik verilebilir.

\section{KAYNAKLAR}

Aydın, B. (2007). Öğretmenlik mesleğindeki kariyer basamaklarına ilişkin öğretmen görüşleri ve bu görüşlerin bireysel değişkenlere göre incelenmesi. Yayınlanmamış Yüksek Lisans Tezi, Dokuz Eylül Üniversitesi, İzmir.

Bakioğlu, A., \& Banoglu, K. (2013). Öğretmenlikte kariyer basamakları uygulamasına ilişkin öğretmen görüşlerinin metaforlar ve sosyal ağ analizi yoluyla incelenmesi. Marmara Üniversitesi Atatürk Eğitim Fakültesi Dergisi, 37, 28-55.

Bakioğlu, A., \& Can, E. (2009). Kariyer basamaklarında yükselme sınavının değerlendirilmesi. 18. Ulusal Eğitim Bilimleri Kurultayı Bildiri Özeti.

Başar, H. (1993). Eğitim denetçisi, rolleri, yeterlilikleri, seçilmesi. Ankara: Pegem Yayıncılık.

Büyüköztürk, Ş., Kılıç Çakmak, E., Akgün, Ö.E., Karadeniz, Ş., \& Demirel, F. (2013). Bilimsel araştırma yöntemleri. Ankara: Pegem Yayıncilık.

Can, E. (2019). Öğretmenlerin meslekî gelişimleri: Engeller ve öneriler. Eğitimde Nitel Araştırmalar Dergisi - Journal Of Qualitative Research In Education, 7(4), 1618-1650.

Canbolat, C. (2011). Öğretmen kariyer basamakları uygulaması ile öğretmen motivasyonu ve örgütsel bağlllık arasındaki ilişkiler. Yayınlanmamış Yüksek Lisans Tezi, Fırat Üniversitesi, Elazıg.

Crehan, L. (2016). Exploring the impact of career models on teacher motivation. Paris: UNESCO.

Creswell, J. W. (2003). Research design: Qualitative, quantitative, and mixed methods approaches (2nd ed.). Thousand Oaks, CA: Sage.

Creswell, J. W., \& Plano Clark, V. L. (2015). Karma yöntem araştırmaları tasarımı ve yürütülmesi (Y. Dede, \& S. B. Demir, Çev. Ed.). Ankara: Anı Yayıncılık (Orijinal Yayın Tarihi: 2011). 
Christensen, L. B., Johnson, B., \& Turner, L. A. (2015). Araştırma yöntemleri: Desen ve analiz. Ankara: Anı.Çakıroğlu, A. (2005). Öğretmen Yeterlikleri ve Kariyer Basamakları. <http://www.fedu.metu.edu.tr/documents/AliCakiroglu.ppt> (16.12.2019 tarihinde internetten indirilmiştir.).

Dağlı, A. (2007). İlköğretim öğretmenlerinin algılarına göre ilköğretim müdürlerinin etkili müdürlük davranışları. Kuram ve Uygulamada Ĕ̆itim Yönetimi, 23(23), 431-442.

Demir, S. B. (2011). Öğretmen kariyer basamakları uygulamasının öğretmenler tarafından değerlendirilmesi. Eğitim ve İnsani Bilimler Dergisi: Teori ve Uygulama, 3, 53-80.

Deniz, B. (2009). Kariyer basamakları uygulamasının öğretmen motivasyonuna etkisi. Yayınlanmamış Yüksek Lisans Tezi, Yeditepe Üniversitesi, İstanbul.

Gülcan, M. G. (2003). Avrupa birliğine adaylık sürecinde Türkiye eğitim sisteminin yapısal sorunları ve yapısal uyum modeli araştırması. Yayınlanmamış Doktora Tezi, Ankara Üniversitesi, Ankara.

Gümüşeli, A. (2005). Öğretmenlikte kariyer sistemine yapılan eleştiriler. Artı@ eğitim Dergisi. http://www.agumuseli.com/modules/weblog/details.php web adresinden 10 Aralık 2018 tarihinde edilmiştir.

Kocakaya, M. (2006). Öğretmenlik kariyer basmaklarında yükselme sistemi"nin öğretmenler tarafindan algılanması. Yayınlanmamış Yüksek Lisans Tezi, Kocaeli Üniversitesi, İzmit.

Kurt, M. (2007). Öğretmen ve yöneticilerin öğretmenlik kariyer basamaklar uygulamasına yükledikleri anlamlar. Yayınlanmamış Yüksek Lisans Tezi, Niğde Üniversitesi, Niğde.

Laçin, N. (2006). İlköğretim öğretmenlerinin kariyer basamaklarında yükselme sisteminde performans değerleme sürecine ilişkin görüşleri: Kütahya ili örneğgi. Yayınlanmamış Yüksek lisans tezi, Çanakkale Onsekiz Mart Üniversitesi, Çanakkale.

Milli Eğitim Bakanlığı (2011). Milli eğitim bakanlığının teşkilat ve görevleri hakkında kanun hükmünde kararname, kararname numarası 652, Resmi Gazete, 14/09/2011 tarih ve 28054 say1.

Milli Eğitim Bakanlığı (2014). Millî eğitim temel kanunu ile bazı kanun ve kanun hükmünde kararnamelerde değişiklik yapılmasına dair kanun. http://www.resmi gazete.gov.tr/eskiler/2014/03/20140314-1.htm adresinden edinilmiştir.

Nartgün, Ş. S., \& Ural, İ. (2007). Kariyer basamaklarında yükselme uygulamasına ilişkin öğretmen görüşleri. Abant İzzet Baysal Üniversitesi Eğitim Fakültesi Dergisi, 7(2), 129-149.

Özdemir, T. Y., \& Orhan, M. (2019). Öğretmenlerin "öğretmenlik mesleğinin imajı" hakkındaki görüşleri. Trakya Ĕ̆itim Dergisi, 9(4), 824-846. 
Sağ, V. (2004). Öğretmenlerin kariyer geliştirme hakkındaki görüşleri ve öğretmenlik mesleğinin kariyer basamakları halinde değerlendirilmesi. Yayınlanmamış Yüksek Lisans Tezi, Kırıkkale Üniversitesi, Kırıkkale.

Sullivan, S., \& Glanz, J., (2015). Okullarda eğitim ve öğretimi geliştiren denetim (s.4) (A. Ünal, Çev. Ed.). Ankara: Anı.

Taşkaya, S. M. (2007). Eğitimde niteliğin arttırılması ve öğretmenlerin statüsünün iyileştirilmesinde kariyer basamaklarının değerlendirilmesi: Konya ili örneği. Yayınlanmamış Doktora Tezi, Gazi Üniversitesi, Ankara.

Tosun, I., \& Yengin Sarpkaya, P. (2014). Öğretmenlerin kariyer basamaklarına ilişkin görüşleri. Electronic Turkish Studies, 9(5), 1971-1985

Turan, B., \& Turan, S. (2009). Çalışma statüleri farklı öğretmenlerin kendi algılarına göre yeterlik düzeyleri. Kastamonu Eğitim Dergisi, 17(3), 799-820.

Turner, U., \& Unruh, A. (1970). Supervision for change and innovation. Boston: Houghton Mifflin Company.

Ural, İ. (2007). Kariyer basamaklarında yükselme uygulamasına ilişkin öğretmen görüşler: Bolu ili örneği. Yayınlanmamış Yüksek Lisans Tezi, Abant İzzet Baysal Üniversitesi, Bolu.

Ural, A. (2011). Öğretmenlik mesleği kariyer basamaklarında yükselme uygulamasına ilişkin müfettiş görüşleri. 3. Uluslararası Katılımlı Eğitim Denetimi Kongresi, 22-24 Haziran 2011, 406-414, Mersin Üniversitesi.

Urfalı, P. (2008). İlköğretim ve ortaöğretim kurumlarnnda görev yapan öğretmenlerin öğretmenlik kariyer basamaklarında yükselme sistemine ilişkin görüşleri. Yayınlanmamış Yüksek Lisans Tezi, Anadolu Üniversitesi, Eskişehir.

Utkutuğ, Ç. P. (2007). Toplam başarn göstergesi yöntemi ve örnek uygulama. Yayınlanmamış Yüksek Lisans Tezi, Ankara Üniversitesi, Ankara.

Yang Keo, S. D. (2016). Changing how schools and the profession are organized: building a foundation for a national system of teacher career ladders at the national center on education and the economy. Unpublished Doctoral Dissertation, Harvard Graduate School of Education.

Yıldırım, A., \& Şimşek, H. (2008). Sosyal bilimlerde nitel araştırma yöntemleri (5. baskı). Ankara: Seçkin Yayıncılık.

Etik Kurul Kararı: Bu araştırma 2020 yılından önce gerçekleşen doktora tezinden üretildiği için etik kurul kararı zorunluluğu taşımamaktadır. 